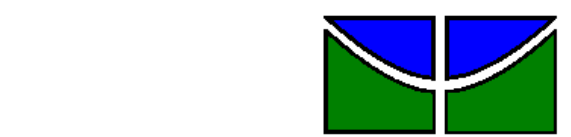

Universidade de Brasília

Faculdade de Economia, Administração e Contabilidade

Departamento de Administração

LARYSSA ROCHA DE SOUZA MAIA

\title{
A INTRANET COMO INSTRUMENTO DE ENDOMARKETING
}

Brasília - DF 


\section{LARYSSA ROCHA DE SOUZA MAIA}

\section{A INTRANET COMO INSTRUMENTO DE ENDOMARKETING}

Monografia apresentada ao

Departamento de Administração como requisito parcial à obtenção do título de Bacharel em Administração.

Professor Orientador: Msc. Walter Eustáquio Ribeiro

Brasília - DF 
Maia, Laryssa Rocha de Souza.

A intranet como instrumento de endomarketing/Laryssa Rocha de Souza Maia. - Brasília, 2010. 66 f. : il.

Monografia (bacharelado) - Universidade de Brasília, Departamento de Administração, 2010.

Orientador: Prof. Msc. Walter Eustáquio Ribeiro, Departamento de Administração.

1. Marketing. 2. Endomarketing. 3. Intranet. I. Título 


\section{LARYSSA ROCHA DE SOUZA MAIA}

\section{A INTRANET COMO INSTRUMENTO DE ENDOMARKETING}

A Comissão Examinadora, abaixo identificada, aprova o Trabalho de Conclusão do Curso de Administração da Universidade de Brasília do (a) aluno (a)

\section{Laryssa Rocha de Souza Maia}

Msc. Walter Eustáquio Ribeiro

Professor-Orientador

Kézia Rozzet Oliveira, Professor-Examinador

\section{Pedro Henrique Melo Albuquerque}

Professor-Examinador

Brasília, 31 de agosto de 2010 
Ao meu pai Ayrton, à minha mãe Lúcia, ao meu irmão Raphael e ao William. Sem a ajuda e compreensão deles nada seria possível. 


\section{AGRADECIMENTOS}

Agradeço a todos aqueles que contribuíram, direta ou indiretamente, para essa conquista. Em especial, gostaria de agradecer minha mãe Lúcia, meu pai Ayrton e meu irmão Raphael. Muito obrigada por todo o apoio e confiança nos momentos difíceis. Obrigada, também, ao professor Walter pela dedicada orientação e incentivo, os quais foram fundamentais para a realização e conclusão deste trabalho. 


\section{RESUMO}

Em um mercado cada vez mais globalizado e competitivo, é imprescindível, para a sobrevivência das empresas, alinhar-se às modernas formas de gestão. Baseado nisso, a implementação do endomarketing vem sendo utilizada com mais freqüência pelas organizações. O marketing interno, ou endomarketing, consiste, basicamente, em um conjunto de ações dirigidas para o público interno com o intuito de fidelizá-los e, consequentemente, promover uma melhoria no ambiente motivacional que repercutirá, diretamente, no lucro obtido pela empresa. Existem várias ferramentas aptas a viabilizar a implementação do endomarketing, dentre elas pode-se citar a intranet, a qual constitui o foco principal da presente pesquisa. O estudo tinha como objetivo averiguar se a intranet pode ser usada como instrumento de endomarketing. Para tanto, foi realizada uma pesquisa censitária com os formandos em Administração da Universidade, com o escopo de apurar o nível de conhecimento dos mesmos acerca do assunto, bem como estudar, um pouco mais, o ambiente de trabalho de tais alunos. Observou-se que a intranet vem sendo usada como um eficaz instrumento de comunicação interna, contudo, no que tange à fidelização de clientes internos, as empresas ainda têm muito o que melhorar.

Palavras-chave: Endomarketing. Intranet. Comunicação Interna. 


\section{LISTA DE ILUSTRAÇÕES}

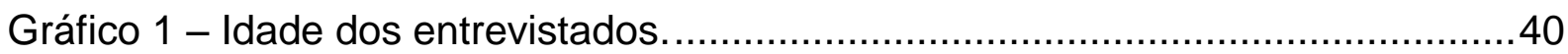

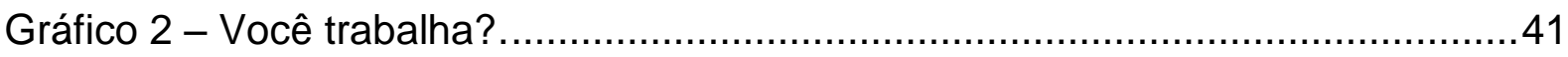

Gráfico 3 - Em que setor você trabalha? ........................................................ 42

Gráfico 4 - Você conhece o conceito de endomarketing? . ......................................44

Gráfico 5 - Você cursou alguma matéria na Universidade que abordou a questão do

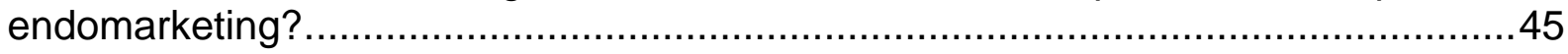

Gráfico 6 - Seu ambiente de trabalho possui intranet? ......................................4

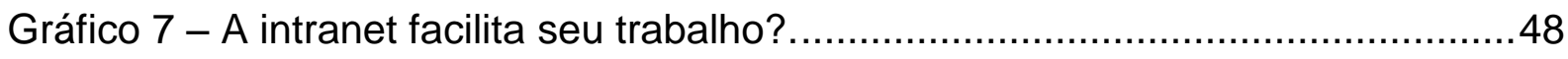

Gráfico 8 - A intranet é um meio de comunicação eficaz na empresa onde você

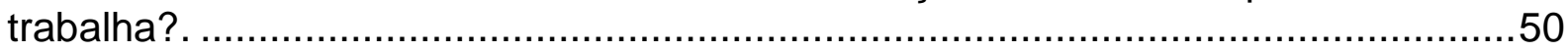

Gráfico 9 - A intranet substitui antigos meios de comunicação na empresa onde você trabalha?

Gráfico 10 - Utilizando a intranet você consegue obter informações importantes sobre a empresa na qual você trabalha?

Gráfico 11 - Utilizando a intranet você consegue perceber que a organização na qual você trabalha está interessada em você e nos seus anseios e opiniões?

Gráfico 12 - Como futuro gestor, você implementaria a intranet como intrumento de endomarketing?. 


\section{LISTA DE TABELAS}

Tabela 1 - Idade dos entrevistados. ................................................................. 41

Tabela 2 - Você trabalha?. .................................................................... 42

Tabela 3 - Em que setor você trabalha? ..................................................... 43

Tabela 4 - Você conhece o conceito de endomarketing? ..................................44

Tabela 5 - Você cursou alguma matéria na Universidade que abordou a questão do endomarketing?

Tabela 6 - Seu ambiente de trabalho possui intranet?..................................47

Tabela 7 - A intranet facilita seu trabalho? ................................................. 49

Tabela 8 - A intranet é um meio de comunicação eficaz na empresa onde você trabalha?.

Tabela 9 - A intranet substitui antigos meios de comunicação na empresa onde você trabalha?

Tabela 10 - Utilizando a intranet você consegue obter informações importantes sobre a empresa na qual você trabalha?

Tabela 11 - Utilizando a intranet você consegue perceber que a organização na qual você trabalha está interessada em você e nos seus anseios e opiniões?

Tabela 12 - Como futuro gestor, você implementaria a intranet como intrumento de endomarketing? 


\section{SUMÁRIO}

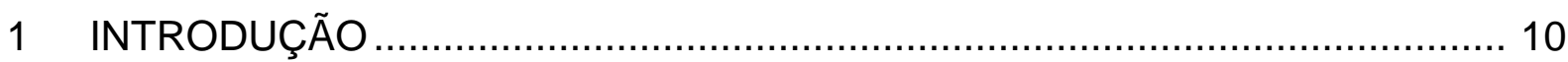

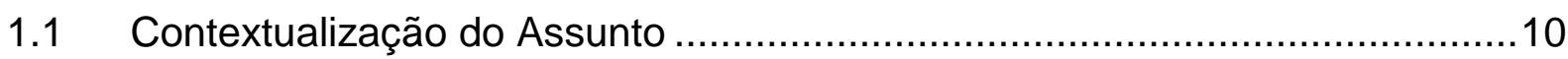

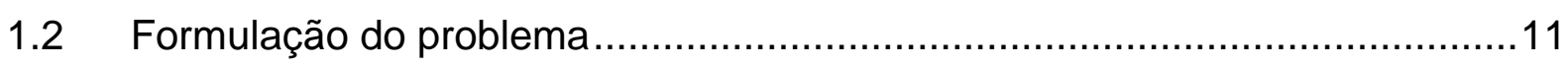

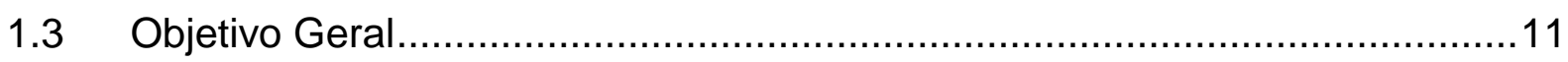

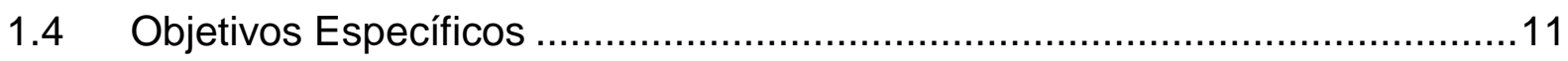

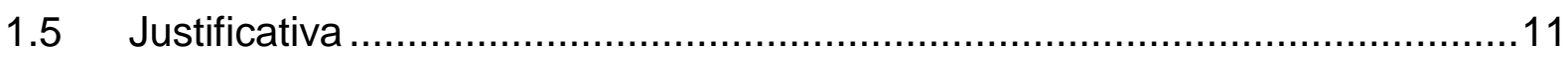

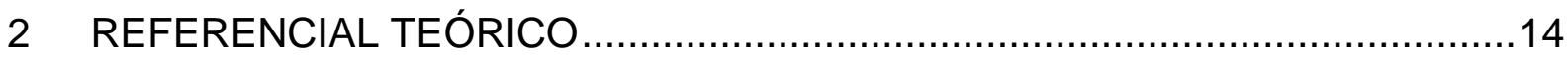

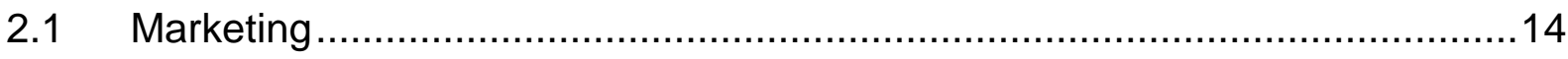

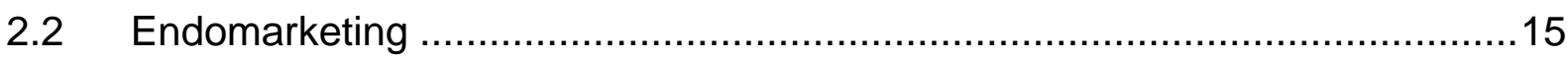

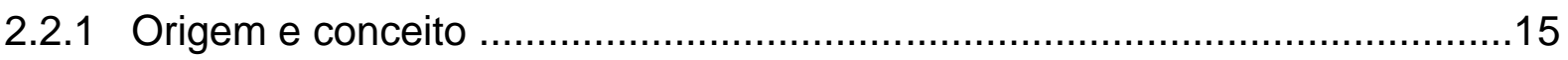

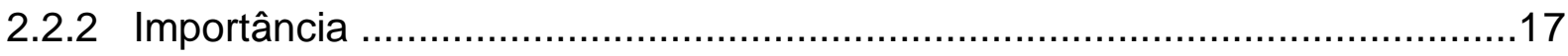

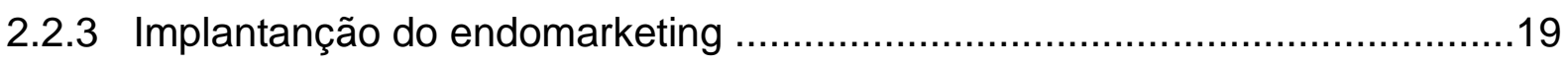

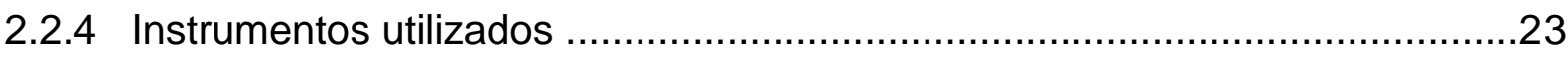

2.2.5 Endomarketing e comunicação interna ………........................................26

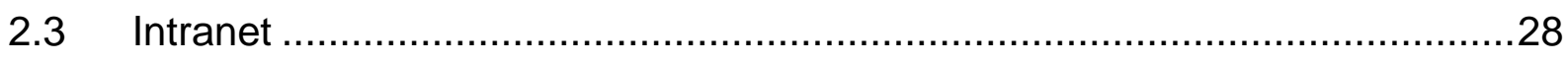

2.3.1 Intranet e comunicação interna ..............................................................

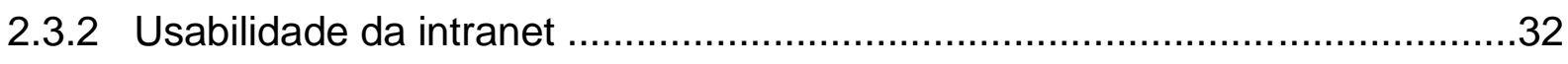

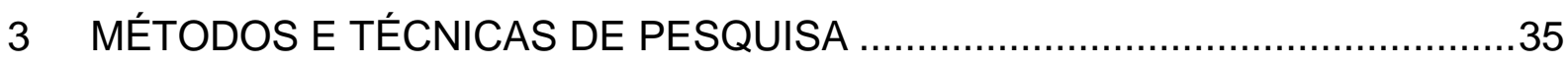

3.1 Tipo e descrição geral da pesquisa ..........................................................35

3.2 Caracterização da organização, setor ou área ............................................36

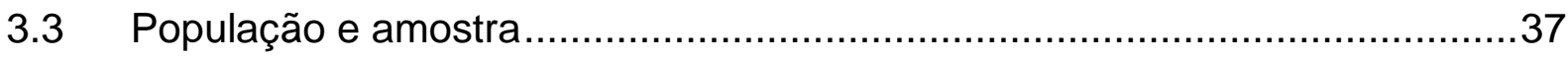

3.4 Caracterização dos instrumentos de pesquisa .............................................37

3.5 Procedimentos de coleta e de análise de dados .........................................38

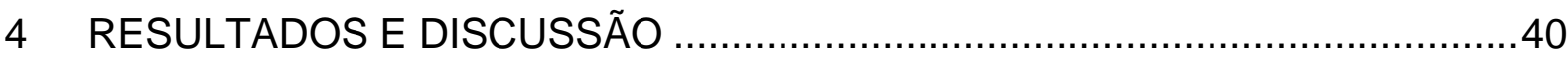




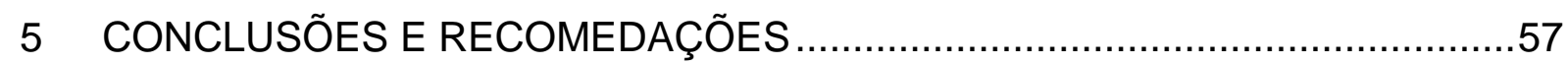

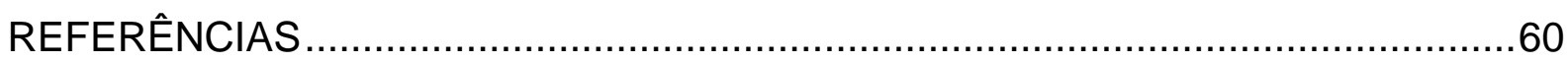

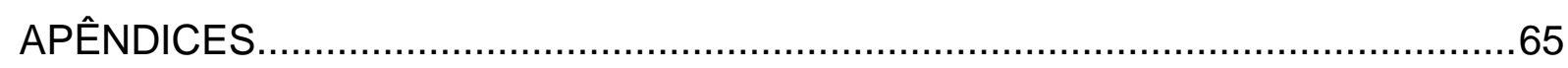




\section{INTRODUÇÃO}

\subsection{Contextualização}

O endomarketing é oriundo da conexão existente entre a área de Marketing e a de Recursos Humanos e consiste em um complexo de ações, voltadas para o cliente interno, que possui como escopo incentivar uma maior interação entre o obreiro e a organização (RIBEIRO, 1993). Essa moderna forma de gestão parte do seguinte pressuposto: "se os produtos, os serviços e as campanhas de comunicação não conseguirem ser compreendidas e vendidas ao público-alvo interno, o marketing tampouco poderá ser bem sucedido junto aos clientes externos" (SILVA, 2005, p. 67). O marketing interno é um poderoso instrumento de gestão, que, gradualmente, está galgando seu espaço nas organizações. É fato incontroverso que, quanto mais coesa estiver a empresa, maiores são suas chances de êxito no mercado profissional (VASCONCELOS, 2004). No intuito de atingir essa coesão, faz-se necessária a utilização do endomarketing, para conseguir o equilíbrio tanto interno quanto externo. Vasconcelos (2004) afirma que "de ferramenta ancilar de marketing, passou a incorporar outras funções, contribuindo assim para o aperfeiçoamento dos processos intra-organizacionais." (VASCONCELOS, 2004, p.37).

Existem várias maneiras de se promover o endomarketing nas organizações e dentre elas pode-se citar a intranet, a qual consiste no foco primordial do presente trabalho. A intranet pode ser conceituada como uma rede interna a qual somente pode ser acessada por pessoas devidamente autorizadas, geralmente funcionários da organização. "Seu principal objetivo é o compartilhamento interno de informações e recursos de uma companhia, podendo ser usada para facilitar o trabalho em grupo e para permitir teleconferências" (ROSS, 2008, p. 5). Por ser uma tecnologia relativamente simples e barata, a intranet vem despertando o interesse dos gestores no que tange à sua utilização como instrumento de endomarketing. 


\subsection{Formulação do problema}

Em rápidas palavras, baseado no que foi dito acima, percebe-se que é importante o gestor alinhar-se às modernas formas de gestão das organizações e, como o capital humano é a principal ferramenta das empresas, faz-se necessário reter e fidelizar os funcionários. Dentre as diversas formas de fidelização, a intranet vem despertando a curiosidade da alta gerência em virtude de ser uma tecnologia relativamente simples e com um custo viável. Assim, o problema da presente monografia de conclusão de curso consiste na seguinte pergunta: a intranet pode ser utilizada como instrumento de endomarketing?

\subsection{Objetivo Geral}

Baseado no problema de pesquisa acima mencionado, verifica-se que o objetivo geral do trabalho foi levantar informações sobre endomarketing e intranet, com o intuito de averiguar se a intranet pode ser utilizada pelas organizações como uma ferramenta rápida e eficaz de endomarketing.

\subsection{Objetivos Específicos}

Dessa maneira, os seguintes objetivos específicos podem ser encontrados como escopo, a fim de dar a devida sustentação para o objetivo geral:

- verificar se a intranet pode ser realmente usada como uma ferramenta de endomarketing;

- verificar como a comunicação interna influencia na implementação do endomarketing;

- verificar a usabilidade da intranet como meio de atuação na logística interna; 
- investigar o nível de conhecimento dos formandos em Administração do $1^{\circ}$ semestre de 2010 da Universidade de Brasília quanto ao tema.

\subsection{Justificativa}

Desde o advento da escola de relações humanas, cujo um dos principais expoentes é o professor Elton Mayo, o homem percebeu que a "ferramenta" mais importante da organização é o fator humano (CHIAVENATO, 2000). Baseado nisso, certifica-se que gerir as pessoas é a peça-chave para o bom funcionamento das empresas. Contudo, nem sempre é fácil adequar a equação capital humano x lucro, haja vista que muitos gestores e presidentes de empresas ainda não se atentaram para a importância de uma boa dirigência no que tange ao público interno.

Assim sendo, verifica-se que o processo de conquista e fidelização do cliente interno, tal qual o cliente externo mostra-se bastante relevante. Contudo, percebe-se que o processo de fidelização do cliente interno ainda encontra sérias resistências por parte de alguns dirigentes, pois muitos o consideram perda de tempo e de dinheiro. Dessa maneira, mostra-se fundamental entender de modo mais detalhado o processo de endomarketing, que pode ser compreendido como o marketing para o cliente interno, ou seja, para os funcionários, com o intuito de que os mesmos "vistam, efetivamente, a camisa da empresa" (BRUM, 1998). Deve-se atentar que, em linhas gerais, o marketing interno privilegia o aumento da motivação do funcionário e constata-se que um funcionário motivado trabalha mais e melhor, o que, por sua vez, irá influenciar diretamente no lucro obtido pelas empresas, pois "aos olhos do cliente consumidor, o funcionário é visto como um especialista ou, no mínimo, como alguém que entende do assunto e conhece a 'verdade' sobre a empresa ou produto/serviço e pode ser sincero em suas informações" (CRESCITELLI, 2005, p. 16).

A importância do tema reside no fato de que o mesmo não está sedimentado no Brasil, sobretudo nas universidades, haja vista que poucos professores de marketing preocupam-se em demonstrar para os alunos a importância do marketing interno. 
Logo, muitos alunos formam-se e não sabem direito o que vem a ser o endomarketing. Tal constatação é deveras preocupante, pois os alunos de hoje serão os futuros gestores e presidentes de empresas de amanhã.

Em razão do endomarketing não possuir um terreno bem fundamentado, principalmente no Brasil, observa-se ser o mesmo um bom tema de pesquisa. $O$ principal objetivo do endomarketing é fazer com que o funcionário sinta-se motivado para trabalhar, aumentando, dessa maneira, o comprometimento com a empresa. Tal comprometimento influi de maneira substancial na conquista e fidelização do cliente externo. Dentre as várias formas de se implementar o endomarketing, esse trabalho de pesquisa se atentará para a possibilidade da intranet ser usada como instrumento eficaz de endomarketing.

No intuito de desenvolver o presente tema, o trabalho monográfico foi dividido em 5 capítulos, sendo o primeiro capítulo a presente introdução.

O segundo capítulo destina-se ao referencial teórico, no qual estão explicitadas as considerações feitas por autores de renome no que tange ao tema proposto. A revisão bibliográfica ateve-se, predominantemente, a livros e artigos científicos. Eventualmente, foram utilizados conceitos elaborados em teses de monografias de mestrado e/ou doutorado.

O terceiro capítulo, por sua vez, refere-se aos métodos e técnicas de pesquisa, no qual estão delineadas informações sobre o tipo de pesquisa, a caracterização do setor pesquisado, os participantes do estudo e os procedimentos de coleta e análise de dados.

O quarto capítulo dispõe acerca da discussão e análise dos dados levantados na pesquisa de campo ocorrida no mês de julho através da aplicação de questionários.

Por fim, no quinto capítulo foram tecidas considerações finais sobre o problema de pesquisa proposto, expondo-se considerações pessoais sobre o tema. 


\section{REFERENCIAL TEÓRICO}

\subsection{Marketing}

“A palavra Marketing teve sua derivação do latim 'mercare', termo que se referia ao ato de comercializar produtos na Roma Antiga" (SANTOS et al., 2009, p. 91).

Posteriormente, no início do século XX, por meio a Administração Científica de Taylor e Ford, ocorreu uma reviravolta no campo do consumo, pois produtos passaram a ser fabricados de maneira massiva. Porém, tais produtos eram produzidos de maneira uniforme, não havendo, portanto, customização. Em razão da uniformidade dos produtos, pode-se afirmar que não havia, ainda, espaço para o marketing (SAMPAIO e SILVA, 2009).

Assim sendo, verifica-se que, somente com o término da $2^{\underline{a}}$ Guerra Mundial, 0 marketing galgou seu espaço no ambiente organizacional das empresas. Isso se deve ao incentivo financeiro e econômico dado pelos Estados Unidos aos países europeus para que os mesmos se reerguessem. Houve, então, um "boom" de empresas, aumentando, assim, a competitividade e, por conseqüência, ações voltadas para o marketing (SAMPAIO; SILVA, 2009).

Atualmente, em razão da modernização, a concorrência entre as empresas encontra-se cada vez mais acirrada. Dessa maneira, gestores estão percebendo que, antes de mesmo tentar conquistar o público externo, a organização deve priorizar o público interno, ou seja, seus próprios funcionários. Isso vem ao encontro da afirmação de Kotler, segundo a qual o "marketing interno deve preceder o marketing externo" (KOTLER, 2000, p. 44). Logo, percebe-se que o marketing o qual antigamente era centrado exclusivamente no público externo; atualmente, concentra-se no público interno, nos seus funcionários, como uma maneira de satisfazer os clientes externos por meio da motivação do público interno (PIZZINATTO, 2008). 


\subsection{Endomarketing}

\subsubsection{Origem e conceito}

O endomarketing, tal como conhecido atualmente, é uma forma de gestão relativamente recente, visto que teve seu início por volta da década de 50, justamente no período de pós-guerra. Entretanto, o "embrião" do endomarketing é um pouco mais antigo pois Henry Ford, no início do século XX, já havia se atentado para o real valor do cliente interno. Para ele, os funcionários da empresa deveriam ser considerados como os primeiros clientes, haja vista tais funcionários estarem diretamente relacionados com a linha de produção, podendo, então, transmitir informações a outras pessoas que não laboravam na organização, fazendo, assim, com que os produtos chegassem ao consumidor final (MENSHHEIN, 2007). Pizzinatto, citando Grönroos, afirma que "nos últimos quinze anos, o conceito de marketing interno surgiu primeiramente na literatura de marketing de serviços e, depois, na literatura de gerência de serviços" (PIZZINATTO, 2008, p. 84).

Por ser um termo relativamente novo, podem-se encontrar diferentes formas de conceituação do vocábulo endomarketing. Cerqueira, por exemplo, conceitua endomarketing como: "conjunto de processos, projetos ou veículos, de comunicação integrada que permita a venda e consolidação de uma nova imagem para dentro da empresa" (CERQUEIRA, 2002). Percebe-se, dessa maneira, que, ao contrário do marketing, o principal foco do endomarketing é a visão interna da organização, ou seja, a empresa deve fazer uma auto-reflexão no intuito de melhorar seu relacionamento com os empregados para que estes sintam-se conscientizados acerca da importância da excelência no atendimento ao cliente (MISHRA, 2010).

Honorato, por sua vez, afirma que "marketing interno é um conjunto de ações da empresa com o propósito de preparar seus funcionários para a cultura do comprometimento com a satisfação dos seus clientes" (HONORATO, 2004, p. 26). Observa-se que o conceito de Honorato está intrinsecamente ligado à noção de treinamento de funcionários. Por meio do adequado treinamento, tais funcionários 
serão capazes de entender a visão, missão e princípios fundamentais que regem a organização, estando, portanto, muito mais aptos e preparados para vender o produto final. Kotler, corroborando essa idéia de treinamento, afirma que marketing interno é a "tarefa bem sucedida de contratar, treinar e motivar funcionários hábeis que desejam atender bem aos clientes" (KOTLER, 2000, p. 44).

Para Brum, o conceito de endomarketing deve ser entendido como "um conjunto de ações utilizadas por uma empresa (ou uma determinada gestão) para vender sua própria imagem a funcionários e familiares" (BRUM, 1998, p. 16). O conceito da eminente pesquisadora é deveras interessante pois ela particulariza ainda mais o endomarketing ao trazer a figura dos familiares. Ao citar os parentes, a autora torna o marketing interno ainda mais íntimo.

Rafiq e Ahmed conceituam endomaketing como o esforço planejado utilizando estratégias mercadológicas direcionadas à motivação dos funcionários, com o intuito de implementação e integração organizacional, voltadas para a orientação do consumidor. (RAFIQ; AHMED, 2002)

Por fim, Brambilla acredita que marketing interno

consiste em uma orientação de marketing voltada para o interior da empresa permitindo que esta crie e promova idéias, projetos e valores úteis à organização, aprimorando as relações com seus funcionários, melhorando 0 atendimento a seus clientes $e$ favorecendo o desenvolvimento da organização como um todo. (BRAMBILLA, 2005, p.10/11)

Verifica-se que cada autor, ao conceituar endomarketing, traz uma peculiaridade. Dessa maneira, observa-se que não há um conceito unânime na doutrina (RAFIQ; AHMED, 2000). Contudo, observa-se que, apesar das particularidades, a essência do instituto é a mesma.

Assim sendo, em resumo, pode-se definir endomarketing como uma forma de propiciar aos funcionários a assimilação de valores básicos que permeiam a empresa com o propósito de motivá-los para o labor, com o escopo de aumentar a produtividade da organização e, indiretamente, os lucros da mesma. É importante que o funcionário se comprometa com a organização e se sinta parte da mesma e não uma mera engrenagem de uma máquina. Dessa maneira, percebe-se que o principal objetivo do endomarketing é "fazer com que todos trabalhem sintonizados 
com o objetivo final da organização (a satisfação do cliente), pois daí é que resultará a sinergia organizacional" (TACHIZAWA; FERREIRA; FORTUNA, 2001, p. 243).

\subsubsection{Importância}

Após a análise do conceito de endomarketing, urge compreender o porquê de ser o mesmo tão importante para as organizações modernas. É extremamente comum ouvir-se, nas empresas, reclamações dos funcionários sobre estes ficarem sabendo dos novos produtos e promoções da empresa através do cliente externo. Tal ação interfere negativamente no comprometimento do funcionário para com a organização, pois o mesmo sente-se traído. Assim sendo, Kempenich afirma: "quando você se esquece do funcionário, você esquece do segundo ou do terceiro aspecto mais importante em termos de grupo de influência e envolvimento" (KEMPENICH, 1997, p.72). De acordo com Brum, "estudos mostram que a maioria das pessoas dedica ao trabalho apenas $25 \%$ da sua capacidade. Os outros $75 \%$ representam a falta de engajamento e a falta de motivação" (BRUM, 1998, p. 27).

Para conter esse sentimento de traição, Maria Cristina Bohnenberger e Ivan Antônio Pinheiro sugerem que "na medida em que os funcionários são informados da situação da empresa (seus produtos e serviços, seu crescimento e prêmios conquistados), desenvolve-se na equipe um sentimento de orgulho" (BOHNENBERGER; PINHEIRO, 2002, p. 4). Um funcionário, que sente orgulho do estabelecimento no qual trabalha, torna-se mais do que um mero empregado e, sim, um parceiro, um colaborador.

A motivação do funcionário é primordial para o bom desempenho de suas funções. No intento de motivar seus funcionários, as empresas devem procurar conhecê-los melhor e de uma maneira mais aprofundada. É nesse quesito que o endomarketing ganha relevância, haja vista possuir, como fundamento, o gerenciamento das pessoas, através da implementação de mudanças nas organizações, no intuito de fazer com que os funcionários "comprem" a essência da empresa. É sua primordial função satisfazer os interesses e as necessidades do cliente interno. 
Empresas que investem em endomarketing possuem mais chances de prosperar no mercado. Em nível internacional, por exemplo, Sam Walton, fundador da rede de supermercados Wal-Mart, sabe a importância do endomarketing para a gestão de uma organização. Assim sendo, ele visita, regularmente, suas lojas para conversar com os clientes e empregados no intuito de averiguar a melhor maneira de prover suas necessidades. Walton acredita fortemente nos benefícios do endomarketing, haja vista seus funcionários terem um canal de comunicação para que expressem seus medos e anseios no que tange a mudanças no cenário mercadológico. Sam Walton acredita que se ele cuidar bem dos seus funcionários, estes cuidarão bem dos consumidores Wal-Mart. (FERREL; HARTLINE, 2007).

Com relação ao mercado brasileiro, a revista Exame Você S/A trouxe, em 2009, o ranking das melhores empresas para se trabalhar no Brasil, sendo que as 3 melhores são empresas da mais alta lucratividade e rentabilidade e que conseguiram um nível de motivação dos seus funcionários superior a $90 \%$. A Caterpillar, empresa que ocupou o $1^{\circ}$ lugar no ranking em 2009, mesmo sentindo os efeitos da crise internacional e despedindo pessoas, conseguiu extraordinários $96,4 \%$ de identificação e comprometimento com a empresa. Esse comprometimento dos funcionários da Caterpillar é fruto de um trabalho árduo que inclui:

- treinamento não só para o cargo que o funcionário ocupa, como também para outras funções;

- investimentos em saúde. Em 2008, foram investidos mais de 32 milhões de reais em programas de saúde;

- salários acima da média do mercado;

- investimentos em educação, os quais superaram 5,5 milhões de reais;

- estímulo à criação de idéias. Funcionários sugeriram, em 2008, 46.315 idéias das quais $79 \%$ foram implementadas;

- diálogo aberto com a chefia superior;

- trabalho voluntário, dentre outros.

Infere-se que, praticamente, todas essas ações são frutos de uma boa implementação de endomarketing. 
No que tange ao mercado brasiliense, há motivos para se comemorar haja vista o Laboratório Sabin ter sido escolhido como a 4⿳亠丷厂 melhor empresa para se trabalhar no Brasil, possuindo índices de identificação e motivação de 94,4\% e 86,8\% respectivamente.

O endomarketing objetiva fortalecer as relações internas dentro da empresa com a função de integrar a noção de cliente $x$ fornecedor interno, o que propicia melhorias tanto na qualidade dos produtos como na produtividade pessoal e qualidade de vida no trabalho. (COBRA; BRAGA, 2004, p.72).

Em resumo, percebe-se que a importância do marketing interno reside em consolidar laços afetivos entre a empresa e o funcionário, formando, dessa forma, uma equipe coesa e unida em busca de um único objetivo ideal, qual seja, a satisfação das necessidades dos clientes, aumentando, conseqüentemente, a lucratividade da organização.

\subsubsection{Implantação do endomarketing}

Após compreender a importância do endomarketing, faz-se necessário entender como funciona o seu processo de implementação em uma empresa. Grönroos afirma que, antes de tudo, deve-se levar em consideração dois importantes aspectos:

Foco interno: deve ser totalmente aceito pela gerência. Os empregados sentem que a gerência os considera importantes quando lhes é permitido participar do processo; tanto no processo de pesquisa interna quanto no planejamento de seus ambientes de trabalho, nas metas e escopo de suas tarefas, nas rotinas de informação e feedback e nas campanhas externas. Quando os empregados compreendem que são capazes de se envolver na melhoria de algo que lhes é importante, eles ficam dispostos a se comprometerem com o negócio e com a estratégia de endomarketing.

Foco externo: O objetivo primordial é o de melhorar a consciência para serviços e clientes e portanto, em última análise, as habilidades de marketing interativo e o desempenho do marketing externo pelos funcionários. (GRÖNROSS, 1993, p. 295) 
Por meio dos ensinamentos de Grönroos (1993) observa-se que o foco do endomarketing é, primordialmente, o público interno, mas percebe-se que tanto o foco interno, como o foco externo devem estar alinhados, não podendo nenhum deles ser menosprezado. Assim, a implementação de um programa de marketing interno traz conseqüências reflexas no que tange ao público externo, pois um funcionário realizado com o seu trabalho vende de maneira muito mais fácil e rápida uma boa imagem da organização para o cliente externo.

Ao implementar um programa de endomarketing, a organização passa a utilizar internamente o instrumental que os profissionais de marketing utilizam para identificar e satisfazer as necessidades dos clientes. Ou seja, nesse caso, os empregados são vistos como clientes internos. (TACHIZAWA; FERREIRA; FORTUNA, 2001, p. 243).

Antes da implementação do endomarketing, os gestores devem ter em mente que o marketing interno deve ser compreendido como um processo gerencial holístico, o qual leva em consideração as diversas funções das empresas de duas formas:

a) assegurando que os funcionários em todos os níveis da empresa, inclusive as gerências, compreendam o negócio e suas várias atividades e campanhas no contexto ambiental;

b) garantindo que todas as pessoas da instituição estejam preparadas e motivadas para agir de forma orientada para os serviços. (COBRA; BRAGA, 2004, p. 73)

Sita Mishra (2010), citando Fisk et. al, afirma que existem duas premissas básicas que devem ser levadas em consideração ao se falar em endomarketing:

- a idéia do empregado como consumidor interno;

- a noção de que a empresa deve satisfazer o consumidor interno para que este esteja melhor preparado para servir o consumidor externo.

Brum (1998) ressalta, em seu livro, seis etapas principais que devem ser seguidas para a implementação de um modelo de endomarketing. São elas:

- pesquisa e diagnóstico: tal qual o marketing externo, no marketing interno, o mercado é que será responsável pela determinação do que será oferecido às pessoas. Assim sendo, torna-se essencial que haja uma pesquisa de clima organizacional para saber do quê a organização necessita. "O clima é representado pelos conceitos e sentimentos que as pessoas partilham a respeito da organização e 
que afetam de maneira positiva ou negativa sua satisfação e motivação para o trabalho" (MAXIMIANO, 2000, p. 107). Gibson (Apud PIZZINATTO, 2008, p. 91 e 92), por sua vez, conceitua clima organizacional como um "conjunto de propriedades do ambiente de trabalho percebidas direta ou indiretamente pelos empregados tidas como sendo a principal força a influenciar a conduta do empregado". Para tal pesquisa de clima, devem ser utilizados questionários. Contudo, deve-se atentar que tais questionários devem ser separados de acordo com o cargo ocupado pelo funcionário. Essa pesquisa tem por escopo, igualmente, avaliar a percepção dos funcionários no que tange a eventuais mudanças. Isso é deveras importante, pois de acordo com Ribeiro "qualquer processo de mudança, se implementado à revelia, tende a ser encarado como benefício unilateral pelos empregados" (RIBEIRO, 1993, p. 77)

- definição da meta global: nada mais é do que determinar o quê se almeja com a implementação do endomarketing. É cabível ressaltar que pode haver mais de uma meta global desde que não haja contradição entre elas e que estas não estejam muito distantes umas das outras. Neste momento, é importante, da mesma forma, que haja um trabalho intenso e eficaz de comunicação interna.

- criação dos ícones de comunicação interna: definida a meta global, passa-se a criação do slogan. Esse slogan consiste em uma frase de fácil assimilação que demonstra o desafio a ser enfrentado e que, ao mesmo tempo, transmita idéias relacionadas ao futuro e a coisas boas que estão por vir. Pode ser produzida, também, uma marca ou personagem.

- divisão do público interno: é a clássica divisão da empresa em uma pirâmide que possui 3 segmentos. No topo da pirâmide encontra-se o presidente e a alta direção, tal segmento possui a função de estabelecer as informações que serão utilizadas no programa de endomarketing. No meio da pirâmide estão as chefias intermediárias que possuem a função de intermediadores, ou seja, eles serão responsáveis por receber as informações da alta chefia e repassá-las aos funcionários do chão de fábrica. Por último, na base da pirâmide estão os funcionários do mais baixo escalão, aos quais devem ser destinadas mensagens de cunho eminentemente emocional. Contudo, Kotler (2000) afirma que as empresas modernas, voltadas para o cliente, costumam inverter essa pirâmide, colocando na base a alta gerência e no topo os clientes. 
- o programa propriamente dito: consiste em "um conjunto de ações e instrumentos criados, produzidos e distribuídos com o objetivo de informar, integrar e encantar o público interno" (BRUM, 1998, p. 85). Tudo isso será repassado aos funcionários por meio de mensagens e informações, por isso, mostra-se fundamental a boa escolha dos canais de comunicação e do modo como tais notícias serão repassadas.

- a escolha de um momento para o lançamento do programa: a sensação de "estarse diante de uma nova era" deve ser clara e transparente. É fundamental que todos os funcionários da organização estejam presentes no momento do lançamento da "campanha", para tanto, recomenda-se que os galpões das fábricas sejam utilizados para o lançamento e que estes estejam decorados com o slogan e marca do programa, fazendo com que o funcionário se sinta em casa.

Honorato (2004), por sua vez, em linhas mais simples, também traz as etapas da implementação de um programa de endomarketing, o qual consistirá em difusão, desenvolvimento e manutenção da cultura do comprometimento. Para ele, é primordial que esteja arraigada na empresa o sentimento de comprometimento para com a organização e o programa que será implementado, caso contrário, os esforços de nada adiantarão.

Brambilla lembra que:

Para uma aplicação efetiva do endomarketing, é fundamental que este constitua como parte da gestão estratégica da organização, e mais do que isto, que esteja devidamente alinhado com os "desejos organizacionais". O apoio dos níveis hierárquicos superiores também é fundamental para tanto, visto que, este plano de ação do marketing interno tenha respaldo e aval positivo por parte dos gestores superiores da organização. (BRAMBILLA, 2005, p.13)

Cerqueira (2002) nos traz, ainda, uma importante lição ao afirmar que não há um período de tempo pré-estabelecido para uma empresa assimilar a cultura do endomarketing, isto é, o período de incorporação da prática do endomarketing irá variar de empresa para empresa.

Urge ressaltar que o endomarketing é um processo vivo e de caráter contínuo. Logo, faz-se necessário haver sempre um feedback do mesmo, principalmente no ato de sua implementação. Dessa maneira, é essencial que exista uma excelente comunicação interna, priorizando o diálogo aberto entre a chefia e seus subordinados. Tal assunto terá aprofundamento posteriormente. 
Por último, deve-se atentar para o fato do marketing interno ser um instrumento multidisciplinar (PIZZINATTO, 2008), ou seja, ele relaciona-se com as mais diversas áreas de uma empresa, em especial com a área de marketing e a de gestão de pessoas. Dessa maneira, é fundamental que exista uma boa interação e cooperação entre esses dois departamentos. Baseando-se nisso, Vasconcelos afirma que:

\begin{abstract}
Observa-se claramente que ele se situa numa região fronteiriça - e, também, por essa peculiar posição estratégica, em condições de facilitar a sinergia entre Recursos Humano $(\mathrm{RH})$ e Marketing, uma vez que é pertinente a ambas as disciplinas. Além disso, há pesquisadores que acreditam ser possível que o resultado da colaboração marketing-recursos humanos possa levar a um maior estreitamento (por exemplo CAHILL, 1995; GREENE, WALLS e SCHREST, 1994, EWING e CARUANA, 1999) ou até mesmo ao desaparecimento das duas funções como departamentos tradicionais (GLASSMAN e MCAFEE, 1992) as quais seriam substituídas por outras mais, digamos, inovadoras, como consumidor gerenciando empregados ou consumidores como associados para empresa (HOOLEY, SAUNDERS e PIERCY, 2001) (VASCONCELOS, 2004, p. 40)
\end{abstract}

\title{
2.2.4 Instrumentos utilizados
}

Para uma melhor compreensão das ferramentas que podem ser empregadas na implementação do endomarketing, este deve ser entendido como gênero, ao passo que seus diversos instrumentos devem ser compreendidos como espécie. Dessa maneira, há uma infinidade de instrumentos que podem ser utilizados para 0 desenvolvimento do endomarketing nas entidades organizacionais.

Brum (1998), em seu livro "endomarketing como estratégia de gestão", elenca os mais diversos meios para a implementação do marketing interno. Dentre os principais estão:

- manual e vídeo de integração à empresa: estão direcionados, principalmente, para o novo funcionário com o intuito de que o mesmo procure saber um pouco mais sobre a organização na qual ele irá trabalhar.

- material de acompanhamento do programa: visam acompanhar todos os estágios do programa de endomarketing, variam de acordo com a duração deste. Programas 
de curta duração podem utilizar, por exemplo, folders; já programas de duração mais longa podem utilizar o jornal do programa.

- manuais técnicos e educativos: muito utilizado em organizações industriais, tais manuais tem por escopo apresentar informações sobre os produtos e/ou serviços para o público interno.

- revistas de histórias em quadrinhos: é uma maneira mais tranqüila de se repassar a informação desejada. Há o emprego de personagens que se assemelham aos funcionários. Tais personagens mostram como a empresa pode atingir suas metas.

- jornal interno: tem por objetivo abordar a vida do funcionário na empresa. Brum afirma, ainda, ser interessante acoplar ao jornal interno um encarte da área de recursos humanos com informações relativas a salários, benefícios, planos de incentivos, dentre outros. É fundamental que haja espaço, igualmente, para o encarte da associação dos funcionários e sindicato de empregados.

- jornal de parede: o grande diferencial de tal ferramenta é a sua visibilidade, visto que o mesmo será fixado em locais nos quais há grande movimentação de funcionários tais quais corredores, perto de banheiros, restaurantes ou cartõesponto.

- cartazes motivacionais: sua principal característica é o fato de serem de fácil memorização. É primordial a utilização de frases simples e curtas, pois o apelo emocional deve ser evidente. "Esse instrumento deve atingir todos os níveis de público interno, além de mostrar ao público externo, que visita a empresa, a sua preocupação com o elemento humano" (BRUM, 1998, p. 105).

- cartazes informativos: possuem um caráter mais formal e sério. É ideal para fases de transições e mudanças nas quais há uma forte resistência e oposição dos funcionários. Tais cartazes objetivam explicar o motivo da ocorrência das mudanças e transições.

- painel do tempo: é composto de três compartimentos de madeira nos quais haverá uma referência ao passado, ao presente e ao futuro, representando, respectivamente, como a empresa estava, como ela está e onde ela pretende chegar. Dessa maneira, os funcionários serão capazes de acompanhar a evolução por meio da análise de gráficos, números, tabelas e demais índices de comparação. 
- painéis motivacionais e decorativos e painéis celulares.

- datas festivas e aniversários dos funcionários: de acordo com Brum (1998), as datas comemorativas que merecem atenção especial são: páscoa, dia das mães, dia dos pais, dia das crianças, natal, reveillon e aniversário da organização. É importante também lembrar o aniversário de cada funcionário com uma singela lembrança.

- caixa postal, ombudsman interno, cartas e cartões: esses instrumentos têm por objetivo melhorar a comunicação entre os funcionários e a alta gerência das organizações, permitindo, assim, uma melhor forma de endomarketing.

- presidente interativo: essa ferramenta permite que todos os funcionários, desde aquele do chão de fábrica até a mais alta dirigência, façam perguntas diretamente ao presidente da corporação. Em regra, utiliza-se um escaninho no qual serão depositadas as perguntas ao presidente, sendo que o mesmo deve respondê-las em até 15 dias. É fundamental que o presidente esteja predisposto a responder todo tipo de indagação que venha a surgir. Pode ocorrer também que tais perguntas sejam feitas pessoalmente, quando as pessoas estiverem, por exemplo, em um auditório. Nesse caso, Brum (1998) batiza a técnica de presidente ao vivo.

- gestão à vista: essa técnica, como o próprio nome já diz, permite que o alto escalão preste contas aos funcionários de categorias mais baixas. Há uma verdadeira inversão na ordem do processo de prestação de contas, pois, naturalmente, é o funcionário quem presta informações à chefia.

- reuniões, palestras e encontros formais tais como o cafezinho ou o café da manhã do mês.

- vídeos informativos e motivacionais: utilizam-se cenas de filmes famosos para trabalhar certas idéias fundamentais no intuito de assegurar a boa convivência interna.

- grife interna: nada mais é que a distribuição de brindes aos funcionários da empresa. Tais brindes devem traduzir o slogan e o espírito da empresa.

- rádio interna e vídeojornal

- correio eletrônico 
- intranet: dentre as ferramentas citadas é o que existe de mais moderno em termos de comunicação interna. De acordo com Brum, intranet é "um sistema interno de dados que permite às pessoas acesso rápido às mais diversas informações sobre a empresa na qual trabalham" (BRUM, 1998, p. 130). Tal instrumento permite que os mais diversos departamentos divulguem entre si o que eles estão fazendo e obtendo em termos de melhorias. É, certamente, uma excelente forma de comunicação e integração dos funcionários, motivo pelo qual é o objeto de estudo do presente trabalho.

Deve-se observar que tais ferramentas não precisam ser utilizadas em caráter exclusivo, podendo haver, inclusive, a combinação delas. A predominância de uma ferramenta sob outras dependerá de uma série de fatores tais como: nível de comprometimento da gestão, tempo disponível, recursos orçamentários, dentre outros. Corroborando tal assertiva:

Todo programa de endomarketing precisa ter uma idéia, um conceito e uma linha criativa. A partir daí, os instrumentos são desenvolvidos de acordo com o porte, o segmento de atuação e a cultura da empresa, permanecendo prontos para receber a informação gerada de acordo com o funcionamento operacional e com a filosofia da organização. (BRUM, 1998, p. 75)

\subsubsection{Endomarketing e comunicação interna}

Para o sucesso na implementação do processo de endomarketing, é fundamental que a organização possua uma excelente comunicação interna visto que:

o endomarketing deverá ser feito visando à melhoria da comunicação
através de meio adequados, auxiliando a evitar e administrar
conflitos, aumentando a produtividade e qualidade, integrando
funcionários e empresas através de parceria, sendo que os
funcionários são o primeiro mercado para a organização. (BARROS,
2007, p. 21 e 22) A existência de uma empresa está baseada na tomada de decisões. Para os dirigentes estabelecerem esta ou aquela estratégia, é necessário que os mesmos estejam munidos de uma ampla gama de informações. "A informação é produto da comunicação interna e a maior estratégia de aproximação funcionário-empresa" 
(BRUM, 1998, p. 30). Dessa maneira, pode-se considerar informação como um punhado de dados impregnados de significação (ZANLUCHI, DAMACENA e PETROLL, 2008).

Zanluchi, citando os ensinamentos de Thayer, ensina que: "à comunicação, por sua vez, está subjacente o processo de transformar os dados, até então brutos, em informações processáveis ou consumíveis, por meio de trocas mútuas" (Apud ZANLUCHI, DAMACENA e PETROLL, 2008, p. 119).

Assim, é extremamente importante que a alta gerência converta suas decisões, 0 mais rápido possível, em informações para o chão de fábrica, caso contrário há grandes possibilidades de ocorrer o que Brum (1998) chama de entropia da informação, que nada mais é do que a famosa "rádio corredor".

A "rádio corredor" é responsável pela deturpação da mensagem. Isso ocorre porque cada pessoa entende a notícia de uma forma diferente. Então, em vez de postergar a veiculação de informações, é necessária a transmissão das mesmas rapidamente para uma boa comunicação interna. Em resumo, o gerente deve buscar meios e formas eficazes de repassar a informação para que não haja uma interferência negativa da "rádio corredor" no que tange à comunicação interna.

Baseando-se nisso, pode-se afirmar que é necessário moldar a informação de acordo com o tipo de público alcançado pela mesma. Ferrell e Hartline afirmam que:

devido a grande diversidade de empregados, atualmente, é pouco provável que um meio ordinário de comunicação conseguirá atingir todos os funcionários eficazmente. As empresas precisam compreender que repassar informações em um formato único de comunicação não é bom para a compreensão do tema. (FERRELL, HARTLINE, 2007, p. 328)

Assim sendo, de nada adianta repassar informações utilizando palavras rebuscadas e formais para uma pessoa que mal completou o ensino primário, ou então, repassar informações via correio eletrônico ou intranet para um indivíduo que é leigo no assunto e, com dificuldades, consegue ligar um computador. Kunsch, afirma que, no momento da comunicação, devem ser levados em consideração "os aspectos relacionais, os contextos, os condicionamentos internos e externos, bem como a complexidade que permeia todo o processo comunicativo“ (KUNSCH, 2002, p.72).

Outro fator, que merece ser lembrado, diz respeito a eventuais barreiras na comunicação existente entre chão de fábrica e alta gerência. É imprescindível que o 
empregado sinta-se à vontade para fazer sugestões e críticas no que tange ao processo organizacional da empresa. Os superiores não podem, de maneira alguma, ser intransigentes no processo de comunicação funcionário-gerência, caso contrário a comunicação tornar-se-á extremamente debilitada e comprometida. Um bom exemplo de como as sugestões dos funcionários podem ser extremamente úteis para a vivência da empresa encontra-se na empresa Caterpillar, já citada anteriormente. Nessa empresa, o diálogo entre funcionários e chefia é totalmente aberto, sendo que aqueles são estimulados a enviar sugestões com o intuito de promover a melhoria da organização. Assim, em 2008, os funcionários sugeriram 46.3145 idéias das quais $79 \%$ foram aproveitadas. Em razão disso, a Caterpillar logrou uma economia equivalente a 1 milhão de reais.

Caso como o citado acima demonstra a importância de uma boa comunicação interna que, por sua vez, reflete na motivação do funcionário, enfatizando, assim, o endomarketing e, por via indireta, a repercussão na lucratividade da empresa.

\subsection{Intranet}

A intranet é um fenômeno relativamente recente, a qual está relacionada, prioritariamente, com a área de tecnologia da informação. Contudo, sua utilidade para as Ciências Sociais, em especial para a Administração, é enorme, haja vista ser um meio rápido e de fácil utilização no que tange à obtenção de informações pelos empregados-usuários.

Em rápidas palavras, a intranet pode ser conceituada como uma "rede interna a uma comunidade" (CARVALHO, 2007, p.76). Tal rede emprega técnicas idênticas às utilizadas na internet, sendo, entretanto, restritas ao ambiente organizacional interno da instituição. Assim,

As intranets, ou também conhecidas como redes locais, são pequenas redes onde os computadores nela ligados conseguem compartilhar recursos e informações. Os recursos podem ser impressoras, conexão à Internet, HDs, entre outros. Já as informações costumam ser os arquivos produzidos e armazenados de cada usuário. (MARTINS, 2007, p. 46) 
As intranets possuem um propósito específico que varia de empresa para empresa e de grupo de usuário para grupo de usuário (CONTE, 2007, p. 16). Assim sendo, não existe um modelo padrão de intranet, pois esta será adaptada de acordo com os interesses e necessidades de cada organização.

Bickel (1998 apud LAUFER 1998, sp) assim conceitua intranet:

a intranet é uma rede interna das instituições que copia o modelo da Internet, oferecendo acesso apenas aos seus usuários devidamente autorizados, que procura disponibilizar informações sobre marketing, pessoal, benefícios e política corporativa.

Greer (1998 apud ROZADOS 2000a, sp), por sua vez, entende que:

uma intranet é uma rede de informática privada que utiliza normas e protocolos da internet, para permitir aos membros de uma organização comunicar-se e colaborar entre si com maior eficácia, aumentando a produtividade.

Cláudia Lopes (2001) compara a intranet com miniaturas de internet, nas quais as empresas podem oferecer os mais diversos serviços da maneira mais simples possível, possibilitando informações acessíveis e compreensíveis, inclusive para a pessoa que não domina a utilização de computadores. Carvalho afirma que:

Os sistemas baseados na intranet privilegiam a informação interna à organização. Em seus estágios iniciais, a intranet é utilizada pelas empresas para divulgar informações sobre os departamentos resoluções da diretoria, jornal interno com notícias selecionadas (clipping) e outros tipos de informações. A intranet pode ser considerada como 0 ambiente de trabalho ideal para compartilhamento de informações dinâmicas e interligadas. (CARVALHO, 2006, p. 76)

O principal objetivo da intranet é "disponibilizar serviços e informações que facilitem a execução das atividades e tarefas de todos os que trabalham para uma organização" (MATOS, 2006, p. 97).

De acordo com Rozados (2000b), uma intranet deve conter 5 atividades principais, são elas:

- correio eletrônico;

- arquivos compartilhados;

- diretórios; 
- buscas;

- administração da rede.

\subsubsection{Intranet e comunicação interna}

A intranet é um importante veículo de comunicação interna dentro de uma empresa. Nos dizeres de Vigneron: "por comunicação interna organizacional entendemos todos os tipos de fenômeno de comunicação que facilitam ou complicam as relações horizontais e verticais nas organizações" (VIGNERON, 2001, p. 97).

Por meio da utilização da intranet, cada departamento da empresa será responsável por produzir sua página eletrônica na qual estarão as principais informações que pretendem repassar para os usuários-funcionários (LOPES, 2000). Verifica-se que tais informações devem ser veiculadas com linguagem acessível para o tipo de público alvo.

Brum afirma que:

A intranet é o que existe de mais recente em nível de comunicação interna, pois permite o marketing para dentro no verdadeiro sentido da expressão, quando um departamento ou área específica pode divulgar ao restante da empresa aquilo que está fazendo, os resultados que vem obtendo e o que pretende implementar em nível de melhorias, além de informações de mercado. (BRUM, 1998, p. 130)

A utilização da intranet como instrumento de comunicação interna possui a vantagem de centralizar a gama de informações dentro de um único canal, o que tende a diminuir a circulação de papéis (SERRA; VALLE, 2006), bem como a perda dos mesmos, fato este muito comum nas organizações modernas, haja vista o imenso volume de informações que circundam as empresas. Vale ressaltar, ainda, que o portal da intranet pode agregar uma série de serviços úteis aos usuários tais como: videoconferência, listas telefônicas internas, grupos de discussão, painéis eletrônicos, base de dados online, notícias sobre novos produtos e lançamentos, groupwares, dentre outros.

O groupware é um processo que permite que os funcionários cooperem entre si, possuindo a rede institucional como utensílio para tanto. Através da utilização do 
groupware diversas questões podem ser discutidas como, por exemplo, atendimento ao cliente, funcionamento e estratégias da empresa, sugestões de melhoria, etc. Um dos principais benefícios do emprego do groupware diz respeito à possibilidade do trabalho "ser colaborativo, sem a necessidade de reuniões, economizando-se tempo e despesas com viagens, além de minimizar os problemas decorrentes da compatibilização de agendas" (SERRA; VALLE, 2006, p. 15).

Originariamente, a intranet era um veículo de comunicação unidirecional, ou seja, as informações eram colocadas no portal e não havia a possibilidade de feedback dos funcionários. Contudo, nas modernas empresas já existe uma total interação, sendo a comunicação, então, bidirecional. Corroborando tal afirmação, Carvalho afirma:

A intranet é um importante veículo de informação interna entre a organização e o funcionário, sendo usualmente caracterizada pela sigla B2E (business to employee) em oposição às siglas utilizadas para os sistemas Web de comércio eletrônico como B2B (business to business) e B2C (business to consumer). Tradicionalmente, a comunicação B2E é unidirecional (da empresa para o funcionário) e passiva (estilo pull, puxe em inglês), no sentido de que a informação está disponível na intranet e o usuário deve buscá-la. A integração de sistemas colaborativos com a intranet faz com que essa última também possa ser caracterizada pela sigla E2E (employee to employee). (CARVALHO, 2006, p. 77)

Para facilitar a comunicação, é fundamental que a intranet possua um layout simples e de fácil manuseio, fazendo com que o usuário-funcionário consiga, sempre que possível, obter a informação desejada quando da utilização do portal, caso contrário podem ocorrer ruídos no processo comunicativo. Ressalta-se, ainda, que a implementação da intranet deve envolver todos os empregados da organização.

Uma intranet bem implantada e bem utilizada deve envolver todos os funcionários de uma empresa, possibilitando a troca de conhecimentos profissionais e até pessoais, numa aproximação entre pessoas de todos os níveis. (BRUM, 1998, p. 131)

Essa troca de conhecimentos, ao permitir a união dos empregados, é responsável por aumentar a motivação do funcionário para com a empresa na qual ele trabalha. Matos afirma, ainda, que:

a implantação da intranet deve ser o resultado de um esforço conjunto e interativo de investimento em tecnologia da informação, comunicação de dados e valorização do relacionamento humano na cultura da empresa. Ela precisa estar integrada a uma estratégia de comunicação interna, sintonizada com os princípios da cultura e diálogo e da abertura para a comunicação. (MATOS, 2006, p. 98) 


\subsubsection{Usabilidade da intranet}

De acordo com a Associação Brasileira de Normas Técnicas (ABNT - NBR 9241-11, 2002), o termo usabilidade, no que tange a computadores, está relacionado à possibilidade do usuário encontrar as informações necessárias, de modo que este consiga atingir suas metas e alcançar suas finalidades. Em outras palavras, usabilidade pode ser entendida como "medida na qual um produto pode ser usado por usuários específicos para alcançar objetivos específicos com eficácia, eficiência e satisfação em um contexto específico de uso" (ABNT - NBR 9241-11, 2002, p. 3). A própria NBR 9241-11 traz a maneira pela qual eficácia, eficiência e satisfação devem ser compreendidas. Assim sendo:

- eficácia: "acurácia e completude com as quais os usuários alcançam objetivos especificos" (ABNT - NBR 9241-11, 2002, p. 3).

- eficiência: "recursos gastos em relação à acurácia e abrangência com as quais usuários atingem objetivos" (ABNT - NBR 9241-11, 2002, p. 3).

- satisfação: "ausência do desconforto e presença de atitudes positivas para com o uso do produto" (ABNT - NBR 9241-11, 2002, p. 3).

Dessa maneira, percebe-se que a usabilidade da intranet está intrinsecamente ligada ao fato dela ser útil para o usuário-funcionário. Logo, verifica-se que o portal eletrônico deve possuir um layout limpo e de fácil manejo, no intuito de satisfazer o empregado e reduzir os erros quando da utilização da intranet.

Entretanto, apreende-se que além dos atributos de eficiência, memorabilidade e redução de erros, as intranets devem ser de fácil aprendizado, permitindo a execução das tarefas com rapidez e o sistema deve ser agradável, permitindo a satisfação subjetiva por parte do servidor. (SERRA; VALLE, 2006, p. 19)

A usabilidade da intranet está relacionada ao fato dela agregar diversos serviços, possibilitando, então, a integração de todos os departamentos de uma dada organização (ROZADOS, 2000a). Sua utilização traz diversos benefícios para a empresa tais como: "ela pode economizar tempo e diminuir custos, compartilhando conteúdos e colaborando tanto no interior da organização como com associados externos e de consórcios" (ROZADOS, 2000a, p. 7). Entretanto, é primordial que se 
faça uma análise do que realmente a organização precisa em termos de informação, inserida no portal, caso contrário a intranet tornar-se-á inútil e obsoleta.

As tarefas podem variar em termos de complexidade (BYSTRÖM e JÄVERLIN, 1995; ZACK, 1998). Em decorrência, o estudo de processos de busca e uso da informação não deve ser feito de forma genérica, como se todas as buscas se dessem a partir de um modelo padrão imutável, independentemente da complexidade da tarefa a ser executada. A complexidade da tarefa efetivamente influencia a quantidade e a diversidade da informação exigida, além de demandar novos esforços do responsável pela busca da informação para verificação quanto à consistência interna da informação obtida (VAKKARI, 2003). (HENRIQUE; BARBOSA, 2009, p. 223 e 224)

Compartilhando com tal informação, Dias assevera que:

Com os inúmeros avanços tecnológicos, muitas instituições sofrem com o excesso de informações, sendo imprescindível a aplicação da gestão da informação para administrar esse caos informacional do mundo digital. Muitas vezes as informações estão armazenadas em equipamentos de informática de forma não integrada, espalhadas em seus bancos de dados, dificultando seu acesso e, consequentemente, o desempenho das atividades necessárias ao pleno funcionamento da instituição. (DIAS, 2001, p.50)

Além disso, Rozados afirma que mais do que um simples instrumento de envio de informações, a intranet pode ser empregada para hospedar fóruns de discussões interativos ou de supervisão de pessoal, agendar reuniões, requerer material e auxiliar na confecção de documentos e desenhos, tudo feito virtualmente, sem a presença física das pessoas (ROZADOS, 2000a).

Tais funções auxiliam, inclusive, na melhoria da logística interna da organização uma vez as informações e instruções de como proceder diante de um problema estarão no portal eletrônico e, sempre que o usuário precisar, poderá acessá-las rapidamente.

Ademais, observa-se que além de ser uma tecnologia de baixo custo de implementação e manutenção, a intranet possui as seguintes vantagens (ROZADOS, 2000a):

- facilidade de uso (uniformidade, facilidade de deslocamento)

- facilidade de publicação e recuperação de dados

- sensação de fortalecimento

- redução de atividades que fazem perder tempo 
Por fim, percebe-se que quando bem utilizada a intranet pode ser uma importante forma de gestão e motivação dos funcionários de uma organização, podendo ser uma notável ferramenta de endomarketing. Dessa maneira, Rozados assim afirma:

a intranet representa uma oportunidade de constituir, de desenvolver e de enriquecer os sistemas de comunicação e de informação internas à organização. Ela permite desmaterializar os suportes de informação, deslocalizar as bases de dados e dessincronizar as ações. Dessa forma a intranet é uma boa ferramenta para simplificar o acesso a informação e melhorar seu armazenamento (ROZADOS, 2000 , p. 10).

Pereira, por sua vez, entende que:

(...) a intranet tenderá a desempenhar um papel cada vez mais importante nos jogos políticos que se desenrolam na organização dos nossos dias, à medida em que aumentam as suas potencialidades técnicas e cresce o conhecimento que cada actor vai adquirindo, por forma a dominar essas mesmas potencialidades. Ao mesmo tempo, as pessoas vão descobrindo na sua utilização um recurso valioso, de acordo com os interesses das suas estratégias pessoais. Por outras palavras, a intranet alarga o campo de actuação dos actores com acesso quer à sua gestão e manutenção, quer à sua utilização, uma vez que, enquanto instrumento de trabalho, se utilizado em todo o seu potencial, pode tornar-se um aliado na redução de incertezas. (PEREIRA, 2004, p. 99) 


\title{
3 MÉTODOS E TÉCNICAS DE PESQUISA
}

\subsection{Tipo e descrição geral da pesquisa}

No intuito de viabilizar o tema de estudo proposto, qual seja, a intranet como instrumento de endomarketing, optou-se por utilizar uma pesquisa exploratória. A pesquisa exploratória, de acordo com Ruiz (2002), possui as seguintes características:

Seu objetivo, pois, consiste numa caracterização inicial do problema, de sua classificação e de sua reta definição. Constitui, pois, o primeiro estágio de toda pesquisa científica; não tem por objetivo resolver de imediato um problema, mas tão-somente apanhá-lo, caracterizá-lo (RUIZ, 2002, p.50).

Após a escolha do tipo de pesquisa, fez-se necessário desenvolver a pesquisa de campo. A pesquisa de campo é frequentemente utilizada nos trabalhos que envolvem áreas relacionadas às Ciências Sociais. Em rápidas palavras,

\begin{abstract}
a pesquisa de campo consiste na observação dos fatos tal como ocorrem respontaneamente, na coleta de dados e no registro de variáveis presumivelmente relevantes para ulteriores análises. Esta espécie de pesquisa não permite 0 isolamento e o controle das variáveis supostamente relevantes, mas permite o estabelecimento de relações constantes entre determinadas condições - variáveis independentes - e determinados eventos - variáveis dependentes -, observadas e comprovadas (RUIZ, 2002, p.50).
\end{abstract}

Para a realização da pesquisa de campo, optou-se pela coleta de dados via questionário, o qual continha 12 perguntas fechadas e 1 pergunta aberta. Ressaltase que não havia a obrigatoriedade de responder à pergunta aberta, ou seja, o respondente só teceria comentários se assim o desejasse. Escolheu-se o questionário em razão de uma série de vantagens, tais quais:

- a possibilidade de ser aplicado, simultaneamente, para o maior número de pessoas possível;

- anonimato; 
- método rápido de coleta de respostas, etc.

A abordagem utilizada na presente monografia, quando da aplicação e tabulação dos questionários no que tange às perguntas fechadas, foi a quantitativa. De acordo com Gressler:

\begin{abstract}
A abordagem quantitativa caracteriza-se pela formulação de hipóteses, definições operacionais das variáveis, quantificação nas modalidades de coleta de dados e informações, utilização de tratamentos estatísticos. Amplamente utilizada, a abordagem quantitativa tem, em princípio, a intenção de garantir a precisão dos resultados, evitar distorções de análise e interpretação (GRESSLER, 2004, p.43).
\end{abstract}

Porém, com relação à pergunta aberta, que era opcional, utilizou-se a pesquisa qualitativa.

Em razão da aplicação de questionários, constata-se que os dados apurados nesse trabalho de conclusão de curso são primários. Eventualmente, foram utilizados dados secundários obtidos em periódicos e artigos científicos.

Além disso, foram utilizados, como apoio metodológico, revisões literárias, principalmente em livros de autores renomados no assunto e, eventualmente, em artigos científicos. Foram feitas, também, consultas em sites disponíveis sobre o assunto. Da mesma forma, casualmente, foram consultadas monografias já apresentadas sobre o devido assunto no intuito de colher opiniões de outros alunos a respeito do tema em questão.

\title{
3.2 Caracterização da organização, setor ou área
}

O público-alvo da aplicação dos questionários foram os formandos em Administração do $1^{\circ}$ semestre de 2010 da Universidade de Brasília - UnB. Assim, não houve a escolha de uma organização específica, motivo pelo qual não se aplica, ao presente trabalho, a caracterização e descrição da organização, setor ou área. Apenas a título de curiosidade, pode-se afirmar que compõe-se, em sua grande maioria, de jovens de até 27 anos que trabalham tanto no setor público, quanto no setor privado. 


\subsection{População e amostra}

A população desta pesquisa foram os formandos do curso de Administração do $1^{\circ}$ semestre de 2010 da Universidade de Brasília - UnB. A escolha foi feita baseada no fato de que estes possivelmente serão futuros gestores de empresas e, como tal, devem estar atentos aos benefícios trazidos pela implementação do endomarketing nas organizações, em especial à intranet como instrumento de endomarketing. É primordial, para o futuro gestor, estar atento às modernas formas de gestão, dentre as quais, destaca-se $o$ endormarketing.

A população deste estudo é composta por 101 estudantes. Ressalta-se, ainda, que a pesquisa foi censitária, ou seja, foram aplicados questionários a todos os formandos. Contudo, nem todos os alunos responderam o questionário, sendo que obteve-se 70 questionários respondidos. Conclui-se, portanto, que a população no presente trabalho é composta de 100 pessoas e a amostra compreende 70 pessoas.

\subsection{Caracterização dos instrumentos de pesquisa}

Os questionários utilizados no presente trabalho foram elaborados pela autora subscritora do trabalho acadêmico de acordo com as necessidades da pesquisa. $\mathrm{Na}$ elaboração dos questionários obteve-se o cuidado de expor os itens com a maior clareza possível, no intuito de assegurar maior precisão nas respostas, evitando-se, dessa maneira, ambigüidade. Para familiarizar o respondente com o tema, foi dada uma pequena explicação no cabeçalho do questionário com o escopo de esclarecer o porquê deste ser selecionado para responder a pesquisa.

Assim sendo, foram elaboradas diversas perguntas as quais estavam alinhadas com os objetivos específicos da presente monografia. As perguntas foram as seguintes:

- idade do aluno;

- se o aluno trabalha, sendo que, em caso de resposta afirmativa, se no setor público ou privado; 
- se o aluno sabe o conceito de endomarketing;

- se teve endomarketing como disciplina na faculdade;

- se o ambiente de trabalho possui intranet;

- se a intranet, em seu ambiente de trabalho, facilita a rotina do aluno;

- se a intranet é um meio de comunicação eficaz na empresa onde trabalha;

- se a intranet substitui antigos meios de comunicação na empresa onde trabalha;

- se a intranet possui informações importantes acerca da empresa na qual o aluno trabalha;

- se por meio da utilização da intranet, o aluno percebe que a empresa está interessada em seus anseios e opiniões;

- se o aluno, como futuro gestor, implementaria a intranet como instrumento de endomarketing na empresa.

Por fim foi apresentada uma pergunta aberta que disponibilizava espaço para o aluno tecer comentários sobre endomarketing e/ou intranet.

Posteriormente, tais questionários foram tabulados e analisados na forma de gráficos e tabelas, evidenciando-se, assim, a utilização de uma análise estatística.

\subsection{Procedimentos de coleta e de análise de dados}

Os dados da presente pesquisa foram coletados ao longo do mês de julho, mais precisamente, nos dias 14, 15 e 28.

A coleta de dados dos dias 14 e 15 de julho ocorreu via eletrônica, ou seja, foram enviados emails para os formandos em Administração solicitando que os mesmos respondessem o questionário enviado. Para assegurar o anonimato do respondente foi feito o seguinte procedimento: assim que o candidato respondia o email, imprimia-se o arquivo contendo suas respostas e apagava-se o mesmo. 
A coleta de dados do dia 28 de julho foi feita de forma presencial, na Universidade de Brasília, durante a aula de Estágio Supervisionado. A escolha do horário e local deveu-se ao fato de agrupar os formandos em um único local e horário. Logo, foram oferecidos aos candidatos, de forma aleatória simples, um questionário autopreenchível, contendo 12 perguntas fechadas e 1 pergunta aberta. Ressalta-se que a pergunta aberta era de caráter opcional, ou seja, o indivíduo-alvo só responderia se assim o desejasse.

Em seguida, com os 70 questionários respondidos, os dados provenientes da análise de campo foram tabulados e analisados em forma de gráficos e tabelas, realçando a utilização de uma estatística descritiva, conforme será evidenciado no capítulo a seguir. No que tange à pergunta aberta, ressalta-se que essa era de caráter opcional. Dessa maneira, somente poucos alunos se dispuseram a respondê-la, assim, ao longo de análise de dados poucas considerações foram tecidas sobre ela. 


\section{RESULTADOS E DISCUSSÃO}

Os dados apresentados a seguir resultam da tabulação e análise de dados decorrentes da aplicação dos questionários aos alunos formandos em Administração da Universidade de Brasília do $1^{\circ}$ semestre de 2010. Com relação à pergunta aberta, foi solicitado que o respondente tecesse algumas considerações sobre a intranet e/ou endomarketing. A resposta a tal pergunta será apresentada no corpo das análises das questões fechadas, no intuito de embasar as mesmas. Assim, tais pessoas serão nominadas pelas letras do alfabeto, quando de sua identificação.

Com relação à idade dos pesquisados, verifica-se que a grande maioria $(64,29 \%)$ é bastante jovem, possuindo idade compreendida no intervalo de 21 a 24 anos. Apenas $10 \%$ dos entrevistados têm idade superior a 28 anos, sendo que $25,71 \%$ dos alunos têm entre 25 a 27 anos, conforme gráfico 1 .

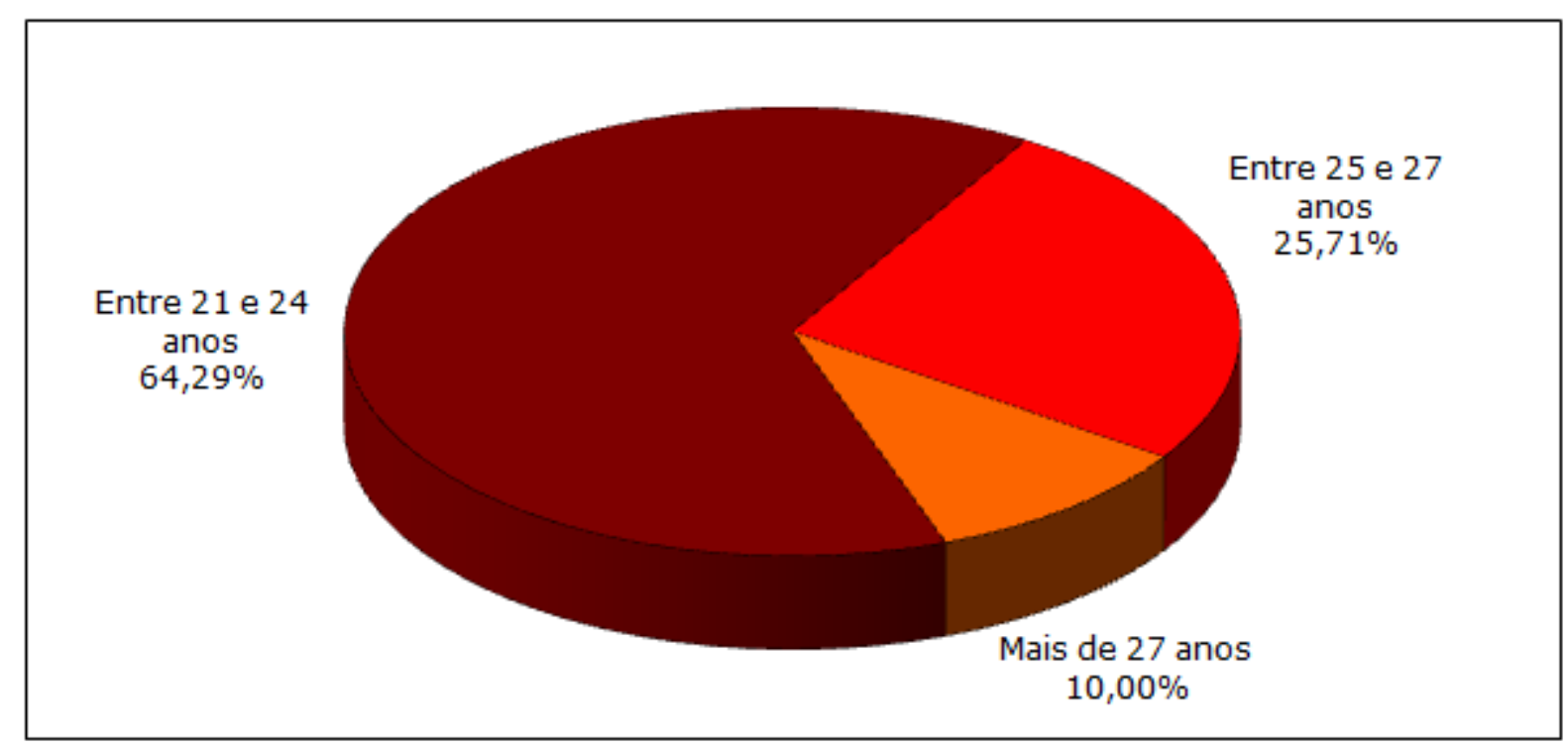

Gráfico 1: Idade dos entrevistados.

Fonte: Dados da pesquisa. 


\begin{tabular}{l|c|c|c}
\cline { 2 - 4 } & Freqüência & Percentual & $\begin{array}{c}\text { Percentual } \\
\text { Válido }\end{array}$ \\
\hline 21 a 24 anos & 45 & $64,29 \%$ & $64,29 \%$ \\
\hline 25 a 27 anos & 18 & $25,71 \%$ & $25,71 \%$ \\
\hline Mais de 27 anos & 7 & $10,00 \%$ & $10,00 \%$ \\
\hline Total & 70 & $100,00 \%$ & $100,00 \%$ \\
\hline $\begin{array}{l}\text { Não } \\
\text { responderam }\end{array}$ & 0 & $0,00 \%$ & \\
\hline Total & 70 & & \\
\hline
\end{tabular}

Tabela 1: Idade dos entrevistados.

Fonte: Dados da pesquisa.

Apesar da pouca idade, observa-se que a maior parte dos alunos já se encontra no mercado produtivo. Dessa maneira, certifica-se que, dos 70 entrevistados, 57 deles, ou seja, $81,43 \%$, estão trabalhando, conforme gráfico 2. Apenas, 13 alunos não exercem labor algum, dedicando-se exclusivamente aos estudos. Ressalta-se que o percentual de alunos que somente estudam é de $18,57 \%$. Contudo, isso não quer dizer que eles nunca tenham trabalhado, apenas significa que, no presente momento, eles não trabalham.

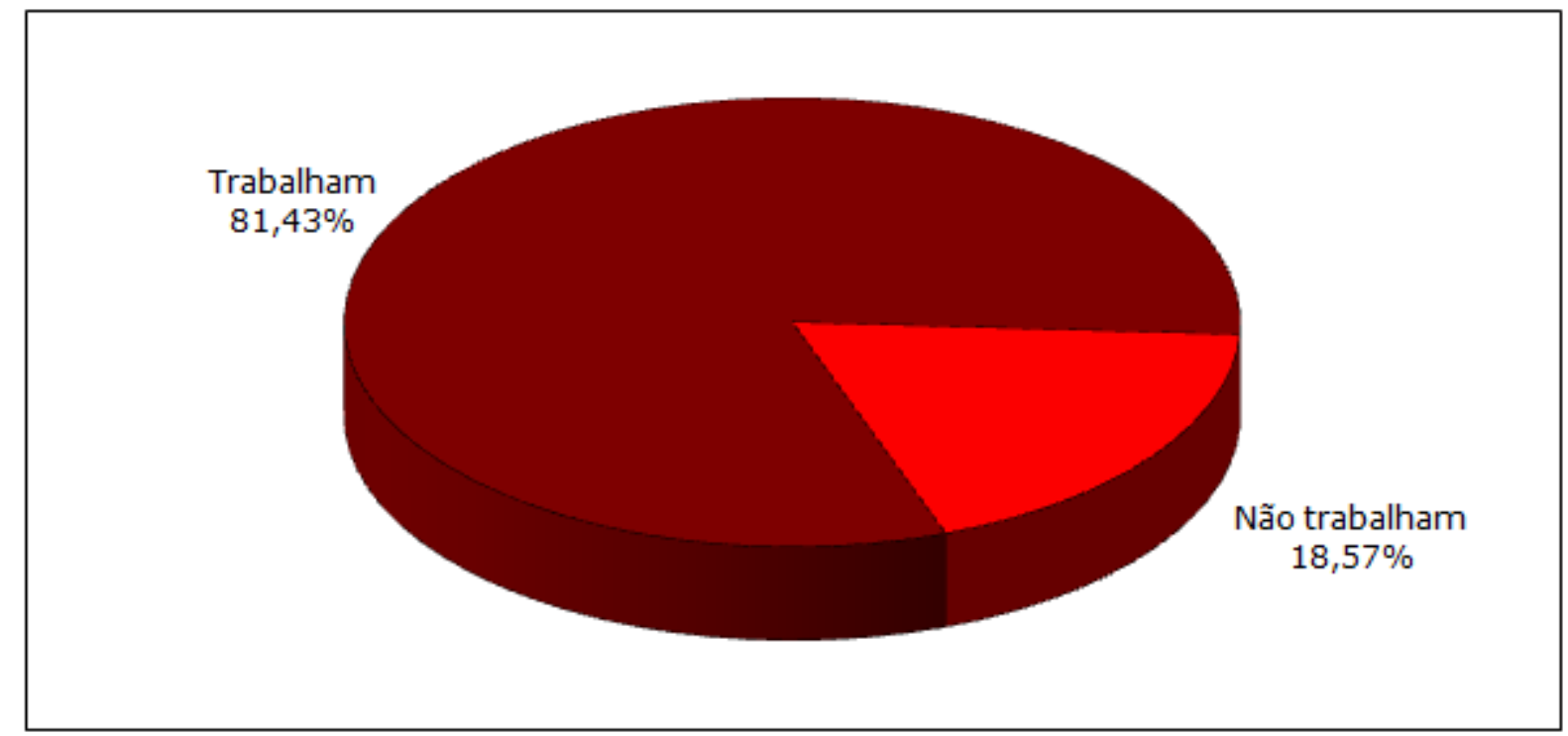

Gráfico 2: Você trabalha?

Fonte: Dados da pesquisa. 


\begin{tabular}{|c|c|c|c|}
\hline & Freqüência & Percentual & $\begin{array}{l}\text { Percentual } \\
\text { Válido }\end{array}$ \\
\hline Trabalha & 57 & $81,43 \%$ & $81,43 \%$ \\
\hline Não trabalha & 13 & $18,57 \%$ & $18,57 \%$ \\
\hline Total & 70 & $100,00 \%$ & $100,00 \%$ \\
\hline $\begin{array}{l}\text { Não } \\
\text { responderam }\end{array}$ & 0 & $0,00 \%$ & \\
\hline Total & 70 & & \\
\hline
\end{tabular}

Tabela 2: Você trabalha?

Fonte: Dados da pesquisa.

A questão 3 do questionário destinava-se somente aos alunos que trabalham. Assim sendo, deve-se ressaltar que, nesta questão, a amostra populacional do presente trabalho não é composta de 70 alunos e, sim, de 57, quantidade, esta, de alunos que responderam que trabalham. Pois bem, dos 57 alunos que desempenham alguma atividade produtiva, 31 deles, ou seja, $54,39 \%$ laboram no setor público; ao passo que 26 estudantes (45,61\%) encontram-se empregados no setor privado, conforme gráfico 3 .

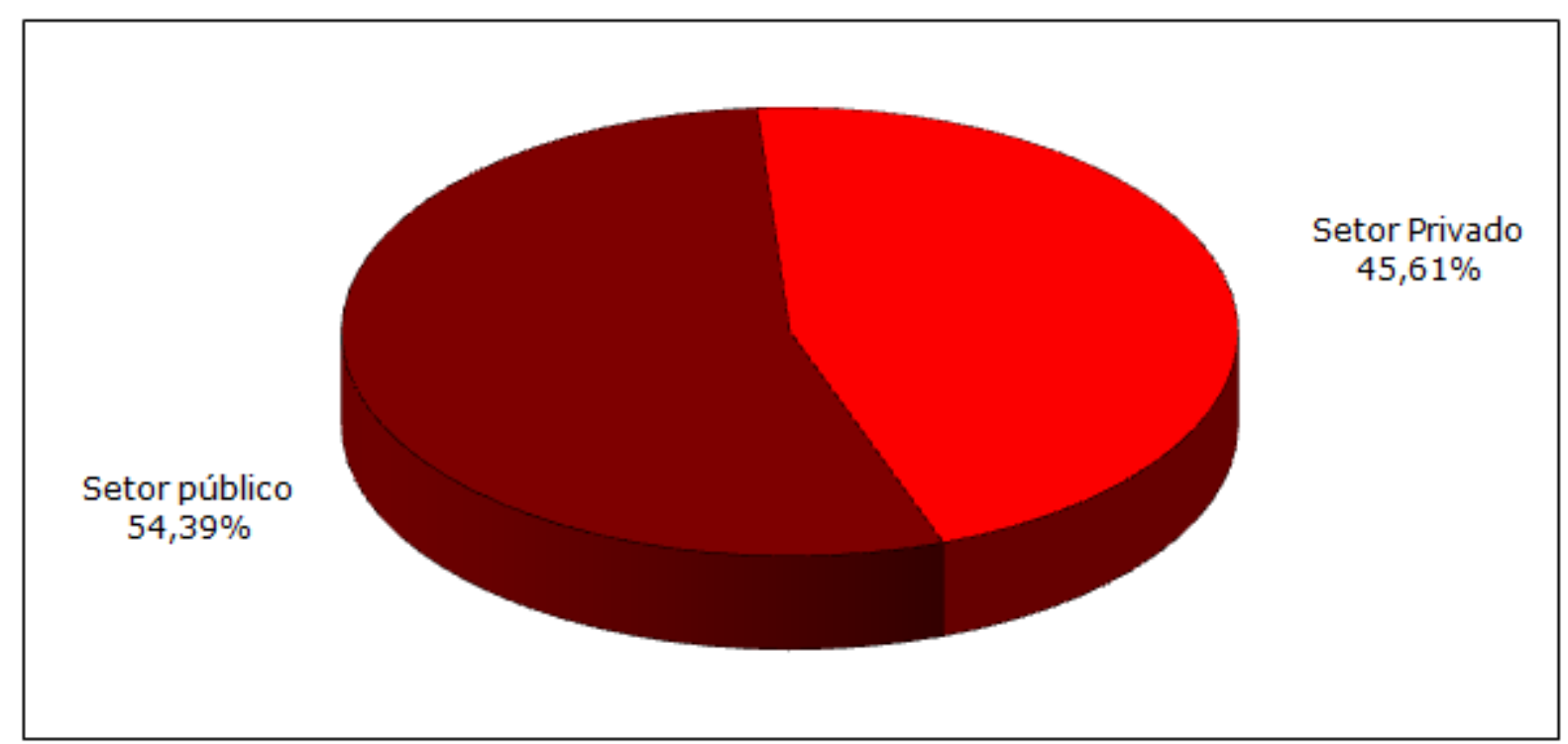

Gráfico 3: Em que setor você trabalha? Público ou privado? Fonte: Dados da pesquisa. 


\begin{tabular}{l|c|c|c}
\cline { 2 - 4 } & Freqüência & Percentual & $\begin{array}{c}\text { Percentual } \\
\text { Válido }\end{array}$ \\
\hline Setor Público & 31 & $44,29 \%$ & $54,39 \%$ \\
\hline Setor Privado & 26 & $37,14 \%$ & $45,61 \%$ \\
\hline Total & 57 & $81,43 \%$ & $100,00 \%$ \\
\hline $\begin{array}{l}\text { Não } \\
\text { responderam }\end{array}$ & 13 & $18,57 \%$ & \\
\hline Total & 70 & & \\
\hline
\end{tabular}

Tabela 3: Em que setor você trabalha? Público ou privado?

Fonte: Dados da pesquisa.

Essas primeiras perguntas tinham o intuito, somente, de conhecer melhor a população pesquisada.

A partir da questão $4 \mathrm{em}$ diante, as perguntas foram elaboradas levando-se em consideração o tema de pesquisa aqui proposto, qual seja, a intranet como instrumento de endomarketing. Assim, foi perguntando aos 70 alunos se estes conheciam o conceito de endomarketing. A conclusão de tal indagação surpreendeu, pois a maioria esmagadora dos alunos conhece o conceito de endomarketing. Assim, 92,86\% responderam que conheciam o conceito de endomarketing, conforme gráfico 4. Apenas 5 alunos responderam que desconheciam o que vem a ser endomarketing. $\mathrm{O}$ entrevistado " $\mathrm{A}$ " inclusive afirmou que:

Considero o Endomarketing vital para que as organizações modernas atinjam mais eficazmente seus objetivos, pois integra 0 quadro de colaboradores à sua missão, motivando-os e fazendo com que estes se sintam peças fundamentais de todo processo de produção, trazendo como conseqüência melhores resultados, que é a razão de ser de toda empresa. (Respondente $\mathrm{A}$ ) 


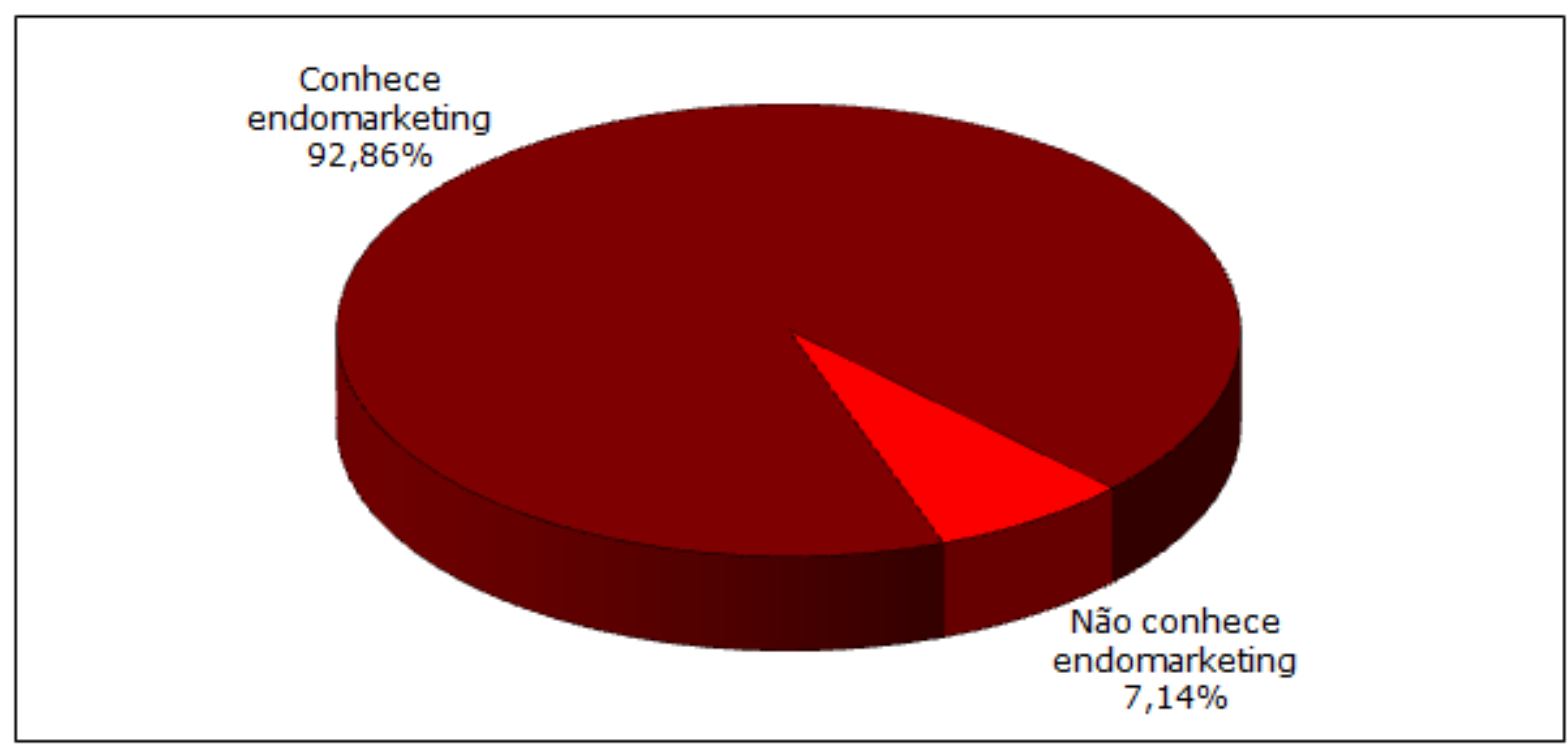

Gráfico 4: Você conhece o conceito de endomarketing?

Fonte: Dados da pesquisa.

\begin{tabular}{|c|c|c|c|}
\hline & Freqüência & Percentual & $\begin{array}{l}\text { Percentual } \\
\text { Válido }\end{array}$ \\
\hline $\begin{array}{l}\text { Conhece } \\
\text { endomarketing }\end{array}$ & 65 & $92,86 \%$ & $92,86 \%$ \\
\hline $\begin{array}{l}\text { Não conhece } \\
\text { endomarketing }\end{array}$ & 5 & $7,14 \%$ & $7,14 \%$ \\
\hline Total & 70 & $100,00 \%$ & $100,00 \%$ \\
\hline $\begin{array}{l}\text { Não } \\
\text { responderam }\end{array}$ & 0 & $0,00 \%$ & \\
\hline Total & 70 & & \\
\hline
\end{tabular}

Tabela 4: Você conhece o conceito de endomarketing?

Fonte: Dados da pesquisa.

Contudo, percebe-se que, muitas vezes, os alunos aprenderam o conceito de endomarketing fora da Universidade de Brasília, por meios próprios, haja vista $42,86 \%$ da amostra ter respondido, na questão 5, que não tiveram nenhuma matéria na faculdade que abordasse a questão do endomarketing, conforme gráfico 5. Isso corrobora o que já fora afirmado anteriormente, mais precisamente na justificativa do tema, que o conceito de marketing interno ainda não está totalmente sedimentado no Brasil, sobretudo nas faculdades, pois os professores não costumam discutir a questão e a importância do marketing interno para o bom desempenho das organizações.

Para alguns autores, como Kotler (2000) e Honorato (2004), o conceito de endomarketing está relacionado a treinamento de funcionários. Brum (1998), por sua vez, ao tecer suas considerações sobre o conceito de endomarketing, traz à tona a 
figura dos familiares, ou seja, a empresa deve vender sua imagem não somente para os funcionários, como também para seus familiares. Silva acredita que o conceito de endomarketing significa "um conjunto de ações de marketing voltado para desenvolver o desempenho mercadológico interno de determinada organização" (SILVA, 2005, p.67).

O respondente $\mathrm{J}$, inclusive, expressou seu desânimo com o fato de não ser mais oferecida, na grade curricular, a matéria "Comportamento Humano nas Organizações", disciplina que, segundo ele, está relacionada com o endomarketing. Senão, vejamos:

Uma importante disciplina em relação ao endomarketing é o comportamento humano nas organizações, que consta como optativa na grade curricular, mas não é formada turma pelo Dept ${ }^{\circ}$ de Adm. da UNB. Em 2008 era fornecido pelo Dept $^{\circ}$, via intranet do CA, uma série de arquivos aos alunos como partilhamento de informações e possibilidade de inserir arquivos, uma espécie de intranet, pena que acabou. (Respondente J)

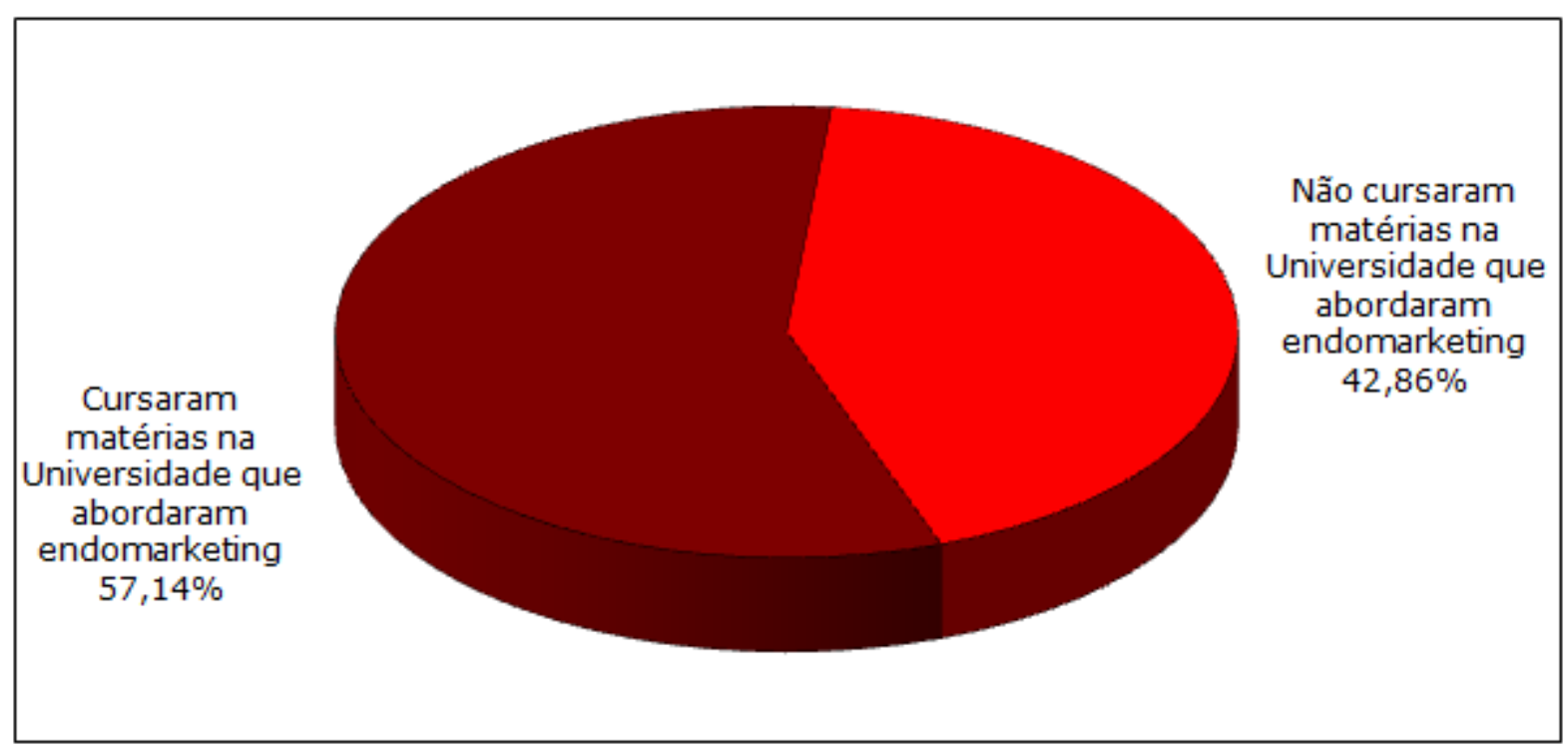

Gráfico 5: Você cursou alguma matéria na Universidade que abordou a questão do endomarketing? Fonte: Dados da pesquisa. 


\begin{tabular}{l|c|c|c}
\cline { 2 - 4 } & Freqüência & Percentual & $\begin{array}{c}\text { Percentual } \\
\text { Válido }\end{array}$ \\
\hline $\begin{array}{l}\text { Cursaram } \\
\text { matérias na } \\
\text { universidade } \\
\text { que abordaram } \\
\text { endomarketing }\end{array}$ & 40 & $57,14 \%$ & $57,14 \%$ \\
\hline $\begin{array}{l}\text { Não cursaram } \\
\text { matérias na } \\
\text { universidade } \\
\text { que abordaram } \\
\text { endomarketing }\end{array}$ & 30 & $42,86 \%$ & $42,86 \%$ \\
\hline $\begin{array}{l}\text { Total } \\
\text { Não } \\
\text { responderam }\end{array}$ & 70 & $100,00 \%$ & $100,00 \%$ \\
\hline Total & 70 & $0,00 \%$ & \\
\hline
\end{tabular}

Tabela 5: Você cursou alguma matéria na Universidade que abordou a questão do endomarketing? Fonte: Dados da pesquisa.

A questão 6, por sua vez, tinha por escopo averiguar se o ambiente de trabalho das 57 pessoas, que responderam "sim" à pergunta 2 , tinha intranet. No que tange a tal indagação, a grande maioria do ambiente de trabalho dos formandos em Administração, possui intranet. Entretanto, conforme será abordado nas questões seguintes, muitas vezes esse poderoso instrumento de comunicação é subutilizado, tornando-se, dessa forma, ineficaz. Apenas 12,28\% dos alunos responderam que o seu ambiente de trabalho não possuía intranet, conforme gráfico 6 . Não obstante, verificou-se que, em resposta à pergunta aberta, há uma organização que apesar de não ter intranet, possui arraigado, na sua cultura, a importância do endomarketing como ferramenta capaz de fidelizar o cliente interno. O respondente I assim se posicionou com relação à questão:

Endomarketing não é SOMENTE intranet, vai além. Por exemplo, na empresa onde trabalho, há painéis de avisos de promovidos, novos colaboradores, vagas em aberto para seleção interna, aniversariantes, colaborador do mês, etc. Também há uma revista trimestral de toda a rede (que é espanhola) e os acontecimentos mais importantes acontecidos em cada unidade e café da manhã dos colaboradores da madrugada com as chefias, já que eles têm pouco contato direto pelo horário. Ademais, existem tarifas diferenciadas para funcionários, amigos e familiares que utilizem os serviços prestados pela organização; treinamento motivacionais, enfim, MAS NÃO TEM INTRANET. (Respondente I) 


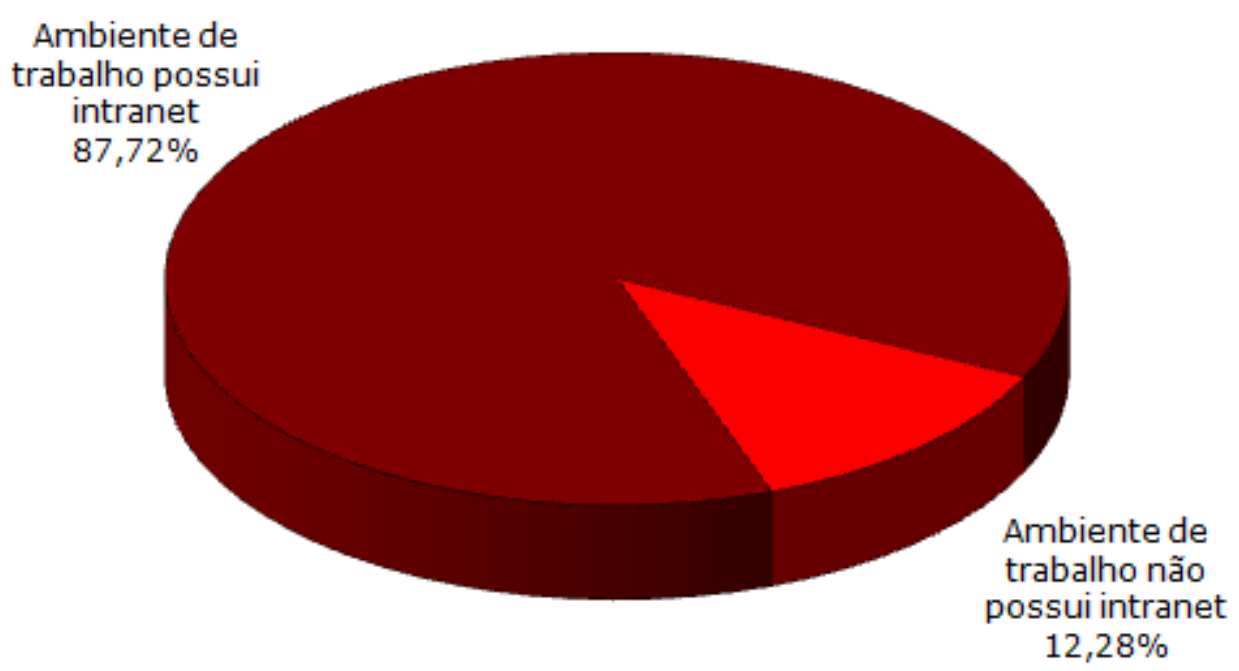

Gráfico 6: Seu ambiente de trabalho possui intranet?

Fonte: Dados da pesquisa.

\begin{tabular}{|c|c|c|c|}
\hline & Freqüência & Percentual & $\begin{array}{l}\text { Percentual } \\
\text { Válido }\end{array}$ \\
\hline $\begin{array}{l}\text { Ambiente de } \\
\text { trabalho possui } \\
\text { intranet }\end{array}$ & 50 & $71,43 \%$ & $87,72 \%$ \\
\hline $\begin{array}{l}\text { Ambiente de } \\
\text { trabalho não } \\
\text { possui intranet }\end{array}$ & 7 & $10,00 \%$ & $12,28 \%$ \\
\hline Total & 57 & $81,43 \%$ & $100,00 \%$ \\
\hline $\begin{array}{l}\text { Não } \\
\text { responderam }\end{array}$ & 13 & $18,57 \%$ & \\
\hline Total & 70 & & \\
\hline
\end{tabular}

Tabela 6: Seu ambiente de trabalho possui intranet?

Fonte: Dados da pesquisa.

A seguir, ressalta-se que, as questões $7,8,9,10$ e 11 possuem amostra de 50 pessoas, pois das 70 entrevistadas, 13 não trabalham, restando assim, 57. Contudo, das 57 pessoas restantes, 7 não possuem intranet em seu ambiente de trabalho.

No que tange à questão 7 , a qual versava sobre a possibilidade da intranet facilitar 0 trabalho das pessoas, verificou-se que $70 \%$ dos formandos julga ser a intranet uma ferramenta apta a facilitar o trabalho, no dia a dia, conforme gráfico 7. A possibilidade da intranet facilitar o trabalho das pessoas deve-se, principalmente, ao fato de que a troca é informações é operacionalizada praticamente em tempo real. Baseado nisso, Ferrante e Rodriguez (2000) afirmam que:

A Intranet tem funcionado nas organizações como um poderoso agente de mudança, pois diferentemente do método tradicional de 
disseminação das informações a Intranet permite identificar as melhores práticas e procedimentos compartilhando praticamente em tempo real com toda organização, facilitando o alcance dos objetivos estratégicos da organização. (Rodriguez; Ferrante, 2000, p. 347)

O respondente $\mathrm{D}$ explicitou sua opinião, com relação a essa questão, no seguinte sentido:

Acredito que a implementação de uma Intranet nas organizações pode facilitar bastante o trabalho dos colaboradores, além de divulgar o posicionamento institucional a respeito dos mais diversos temas que a organização lida no seu cotidiano. O grande problema que vejo nas intranets das organizações é a quantidade muito reduzida de informações relevantes para a maioria dos colaboradores. Outro ponto que deixa a desejar é a falta de interatividade entre as diversas áreas das organizações, muitas vezes você precisa de uma informação simples da área $X$, mas não encontra isso na Intranet. (Respondente D)

Já o respondente $H$, por sua vez, afirmou que:

Acho importante por facilitar a comunicação de maneira vertical e horizontal. Além, disso, a empresa pode fazer divulgações, informar metas, objetivos, ações e propósitos de negócio. Os funcionários podem ter acesso a ouvidoria, o que torna mais acessível à empresa ter o feedback dos mesmos, para aplicação de melhorias, bem como saber como atender melhor as necessidades de seus membros internos. (Respondente $\mathrm{H}$ )

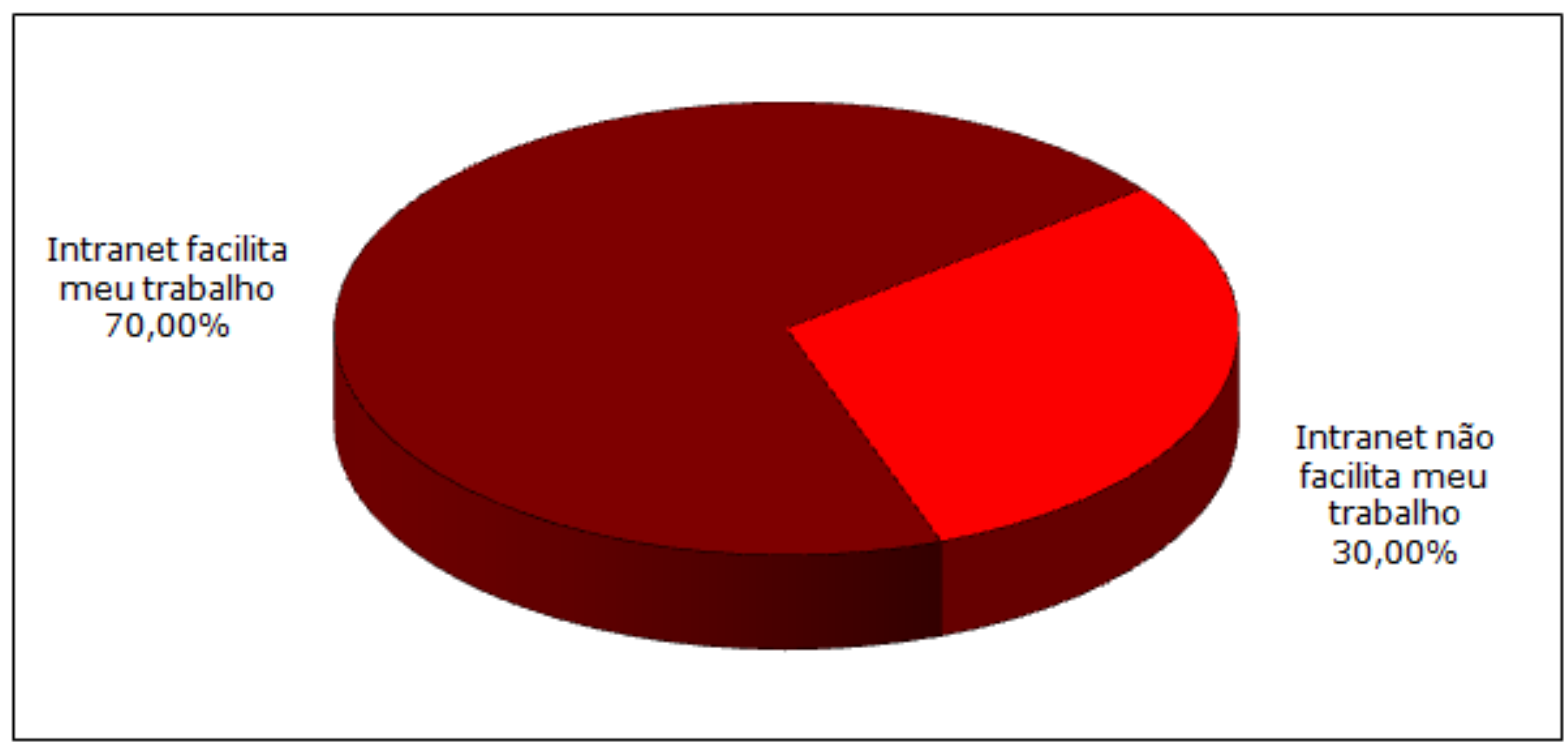

Gráfico 7: A intranet facilita seu trabalho?

Fonte: Dados da pesquisa. 


\begin{tabular}{l|c|c|c}
\cline { 2 - 4 } & Freqüência & Percentual & $\begin{array}{c}\text { Percentual } \\
\text { Válido }\end{array}$ \\
\hline $\begin{array}{l}\text { Intranet facilita } \\
\text { meu trabalho }\end{array}$ & 35 & $50,00 \%$ & $70,00 \%$ \\
\hline $\begin{array}{l}\text { Intranet não } \\
\text { facilita meu } \\
\text { trabalho }\end{array}$ & 15 & $21,43 \%$ & $30,00 \%$ \\
\hline Total & 50 & $71,43 \%$ & $100,00 \%$ \\
\hline $\begin{array}{l}\text { Não } \\
\text { responderam }\end{array}$ & 20 & $28,57 \%$ & \\
\hline Total & 70 & & \\
\hline
\end{tabular}

Tabela 7: A intranet facilita seu trabalho?

Fonte: Dados da pesquisa.

A questão 8 trata sobre a possibilidade da intranet ser um meio de comunicação eficaz na empresa onde $\mathrm{o}$ aluno trabalha. $\mathrm{O}$ objetivo de tal questão era aferir se o fato de haver uma rede interna instalada na empresa facilitaria a comunicação entre os departamentos, desobstruindo, assim, os canais de comunicação, no intuito de evitar ruídos e distorções no processo comunicativo.

Dos 50 alunos, 64\% responderam que a intranet é um meio de comunicação eficaz na sua empresa, ao passo que $36 \%$ afirmaram que a intranet não é um meio de comunicação eficaz no seu ambiente de trabalho, conforme gráfico 8 . O fato da intranet não ser um poderoso meio de comunicação eficaz nessas empresas pode estar relacionada ao fato dos empregados não estarem familiarizados com esse tipo de tecnologia. Assim, "não basta criar condições de acesso à rede, é necessário também favorecer a criatividade e suscitar a emergência de uma forte comunidade eletrônica" (VIGNERON, 2001, p. 100).

Considero a intranet uma forma bastante eficaz de comunicação dentro das organizações, na medida que confere agilidade e rapidez na transmissão de informações. Nas organizações nas quais trabalhei, a intranet é usada basicamente para transmitir informações relacionadas a gestão de pessoal, comunicados internos e afins; além desses usos, acho que poderia ser utilizada também, estrategicamente, na execução dos trabalhos e processos que "tramitam" por diversas áreas dentro da organização, como mais uma forma de integração interna. (Respondente E)

O respondente $\mathrm{F}$ também confirma a eficácia da intranet como meio de comunicação ao demonstrar que:

A intranet é uma ferramenta muito importante da comunicação empresarial, já que hoje as empresas podem possuir diversas filiais e milhares de funcionários, tornando a comunicação em massa um 
grande desafio para fornecer informações de importância tanto para empresa quanto para o funcionário, abordando aspectos estratégicos e/ou operacionais. (Respondente F)

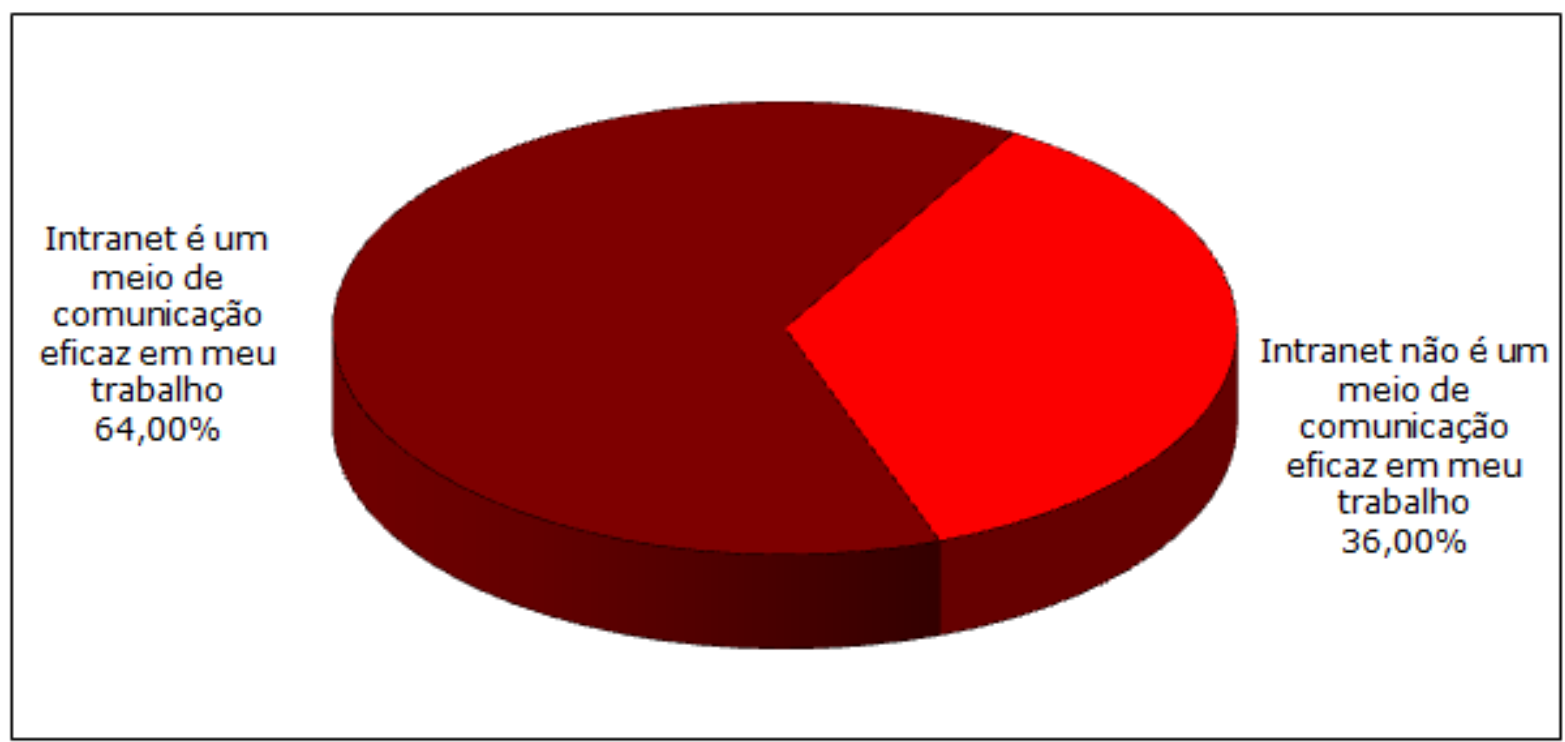

Gráfico 8: A intranet é um meio de comunicação eficaz na empresa onde você trabalha? Fonte: Dados da pesquisa.

\begin{tabular}{l|c|c|c}
\cline { 2 - 4 } & Freqüência & Percentual & $\begin{array}{c}\text { Percentual } \\
\text { Válido }\end{array}$ \\
\hline $\begin{array}{l}\text { Intranet é um } \\
\text { meio de } \\
\text { comunicação } \\
\text { eficaz em meu } \\
\text { trabalho }\end{array}$ & 32 & $45,71 \%$ & $64,00 \%$ \\
\hline $\begin{array}{l}\text { Intranet não é } \\
\text { um meio de } \\
\text { comunicação } \\
\text { eficaz em meu } \\
\text { trabalho }\end{array}$ & 18 & $25,71 \%$ & $36,00 \%$ \\
\hline \begin{tabular}{l} 
Total \\
\hline $\begin{array}{l}\text { Não } \\
\text { responderam }\end{array}$
\end{tabular} & 50 & $71,43 \%$ & $100,00 \%$ \\
\hline Total & 70 & $28,57 \%$ & \\
\hline
\end{tabular}

Tabela 8: A intranet é um meio de comunicação eficaz na empresa onde você trabalha? Fonte: Dados da pesquisa.

Intrinsecamente ligada à questão 8, a indagação 9 tinha como propósito verificar se a intranet substitui antigos meios de comunicação nas empresas onde os respondentes trabalham. A grande maioria dos alunos, 62\%, respondeu que a intranet não substitui os antigos meios de comunicação, conforme gráfico 9. Apesar não ter sido requisitado, estes informaram que o principal meio de comunicação ainda continua sendo o correio eletrônico. $O$ fato da intranet não conseguir substituir 
antigos meios de comunicação deve-se a vários fatores. Uma possível causa seria não ter sido realizada uma pesquisa antes da implementação da intranet com o intuito de procurar saber as necessidades da organização.

A questão principal a ser analisada antes da implantação da intranet é o perfeito entendimento do poder de comunicação que este recurso possui, sendo portanto a definição das informações que devem prioritariamente transitar via intranet um importante aspecto a ser discutido. (Rodriguez; Ferrante, 2000, p. 347)

O entrevistado "B" inclusive afirmou que em sua empresa: "a intranet seria como um complemento, mas não substitui outros meios de comunicação, como emails corporativos, boletins informativos, etc" (Respondente B).

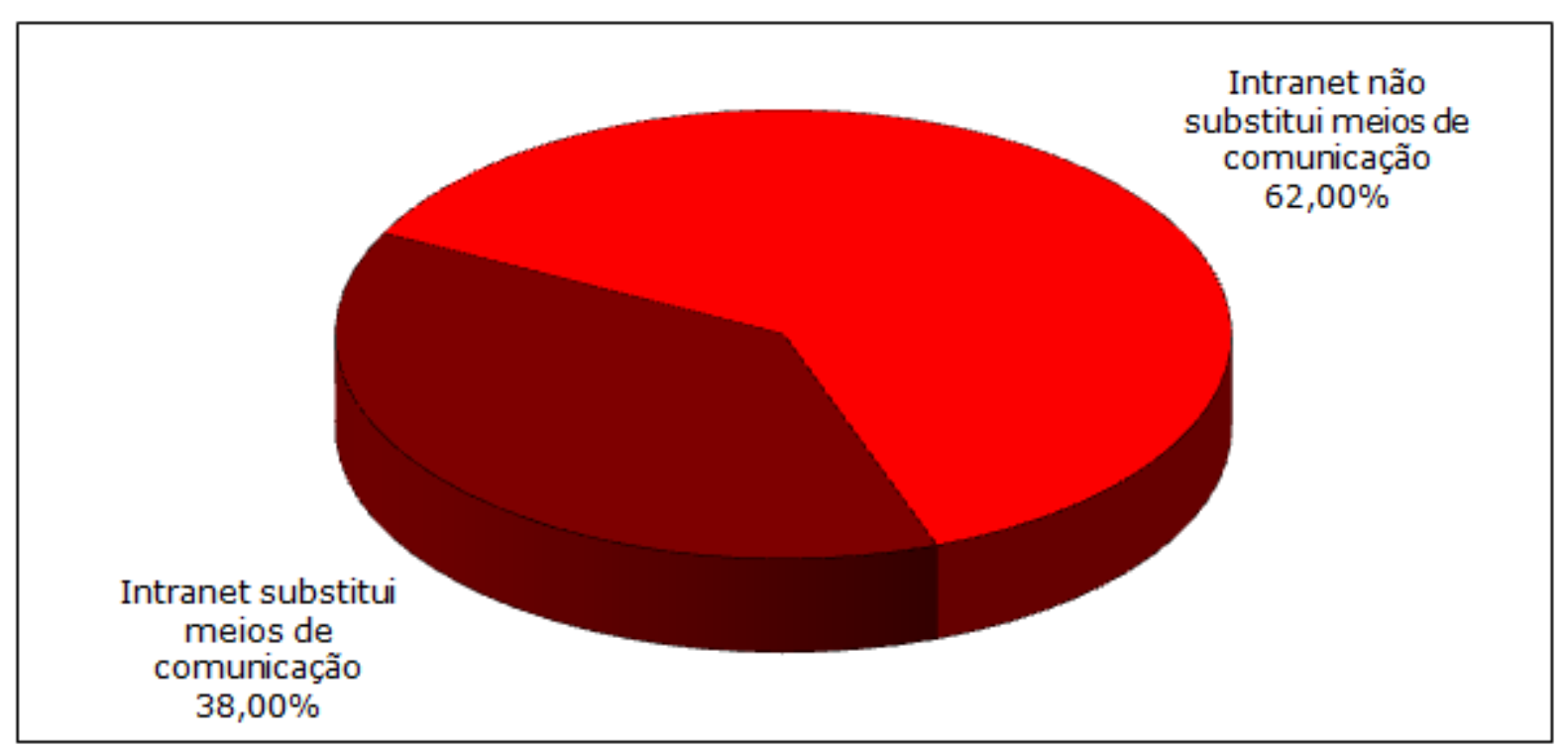

Gráfico 9: A intranet substitui antigos meios de comunicação na empresa onde você trabalha? Fonte: Dados da pesquisa. 


\begin{tabular}{l|c|c|c}
\cline { 2 - 4 } & Freqüência & Percentual & $\begin{array}{c}\text { Percentual } \\
\text { Válido }\end{array}$ \\
\hline $\begin{array}{l}\text { Intranet substitui } \\
\text { meios de } \\
\text { comunicação }\end{array}$ & 19 & $27,14 \%$ & $38,00 \%$ \\
\hline $\begin{array}{l}\text { Intranet não } \\
\text { substitui meios } \\
\text { de comunicação }\end{array}$ & 31 & $44,29 \%$ & $62,00 \%$ \\
\hline Total & 50 & $71,43 \%$ & $100,00 \%$ \\
\hline $\begin{array}{l}\text { Não } \\
\text { responderam }\end{array}$ & 20 & $28,57 \%$ & \\
\hline Total & 70 & & \\
\hline
\end{tabular}

Tabela 9: A intranet substitui antigos meios de comunicação na empresa onde você trabalha? Fonte: Dados da pesquisa.

Com relação à possibilidade de se obter informações importantes sobre a empresa no portal eletrônico, observa-se que $84 \%$ dos "entrevistados" conseguem obter informações valiosas a respeito da organização na qual trabalham, conforme gráfico 10. Apenas $8(16 \%)$ alunos alegaram não conseguir obter tais informações na intranet de suas empresas.

O site da intranet deve conter apenas as informações necessárias para a realização do trabalho. Assim, se o portal congrega uma ampla gama de informações, o funcionário pode se sentir "perdido" diante de inúmeros links e o propósito da intranet não será alcançado, pois a mesma se igualará a internet a qual, atualmente, segundo Brum (1998), está "contaminada" com poluição sonora e visual dispersa, "de onde os profissionais devem peneirar as informações que the interessam para criar oportunidades de negócio" (BRUM, 1998, p.131). Essa afirmação é corroborada, como já evidenciado anteriormente, por Dias:

Com os inúmeros avanços tecnológicos, muitas instituições sofrem com o excesso de informações, sendo imprescindível a aplicação da gestão da informação para administrar esse caos informacional do mundo digital. Muitas vezes as informações estão armazenadas em equipamentos de informática de forma não integrada, espalhadas em seus bancos de dados, dificultando seu acesso e, consequentemente, o desempenho das atividades necessárias ao pleno funcionamento da instituição. (DIAS, 2001, p.50)

O entrevistado $\mathrm{C}$, ratificando o entendimento das autoras acima, afirmou que: "muitas instituições não possuem equipes especializadas na estruturação das informações que são disponibilizadas pela intranet" (Respondente C). 


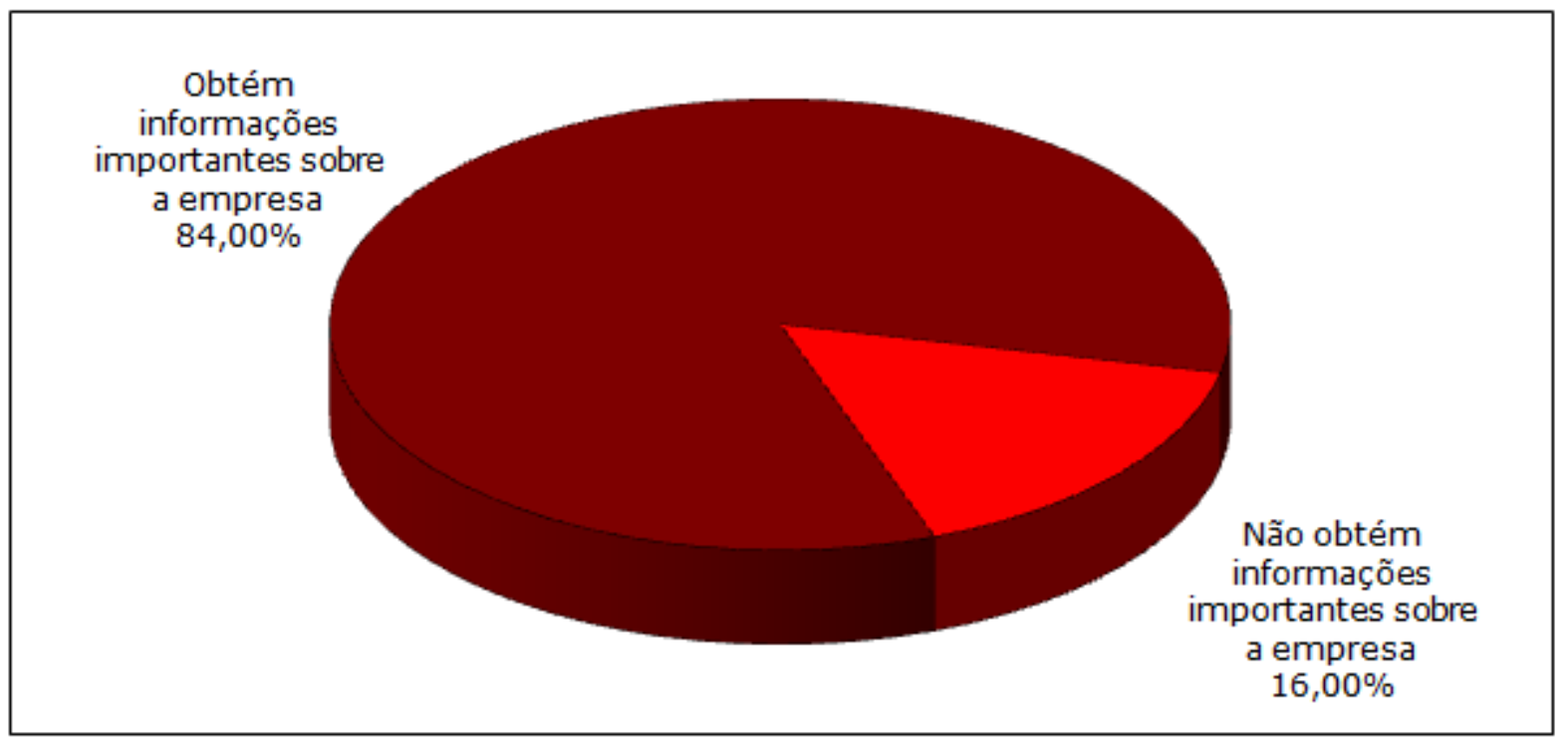

Gráfico 10: Utilizando a intranet você consegue obter informações importantes sobre a empresa na qual você trabalha?

Fonte: Dados da pesquisa.

\begin{tabular}{l|c|c|c}
\cline { 2 - 4 } & Freqüência & Percentual & $\begin{array}{c}\text { Percentual } \\
\text { Válido }\end{array}$ \\
\hline $\begin{array}{l}\text { Obtém } \\
\text { informações } \\
\text { importantes } \\
\text { sobre a empresa }\end{array}$ & 42 & $60,00 \%$ & $84,00 \%$ \\
\hline $\begin{array}{l}\text { Não obtém } \\
\text { informações } \\
\text { importantes } \\
\text { sobre a empresa }\end{array}$ & 8 & $11,43 \%$ & $16,00 \%$ \\
\hline $\begin{array}{l}\text { Total } \\
\text { Não } \\
\text { responderam }\end{array}$ & 50 & $71,43 \%$ & $100,00 \%$ \\
\hline Total & 20 & $28,57 \%$ & \\
\hline
\end{tabular}

Tabela 10: Utilizando a intranet você consegue obter informações importantes sobre a empresa na qual você trabalha?

Fonte: Dados da pesquisa.

A penúltima questão fechada do questionário é, sem sombra de dúvidas, a mais importante na medida em que pergunta ao respondente se, por meio da utilização da intranet, ele consegue perceber que a organização na qual trabalha está interessada nos funcionários, seus anseios e opiniões. Os dados levantados a partir dessa questão demonstram que, apesar da ampla maioria das organizações possuir intranet, esta não é vista, ainda, como um instrumento consolidado de endomarketing, pois apenas $66 \%$ dos entrevistados sentem que a empresa está atenta a suas vontades, conforme gráfico 11. Isso corrobora a afirmação dita anteriormente que, diversas vezes, as empresas simplesmente disponibilizam no 
portal um monte de informação desconexa e, não levam em consideração, anseios e necessidades de seus clientes internos. Encarada dessa forma, a intranet se torna somente mais um instrumento sem nenhuma aplicação prática na vida organizacional de uma empresa.

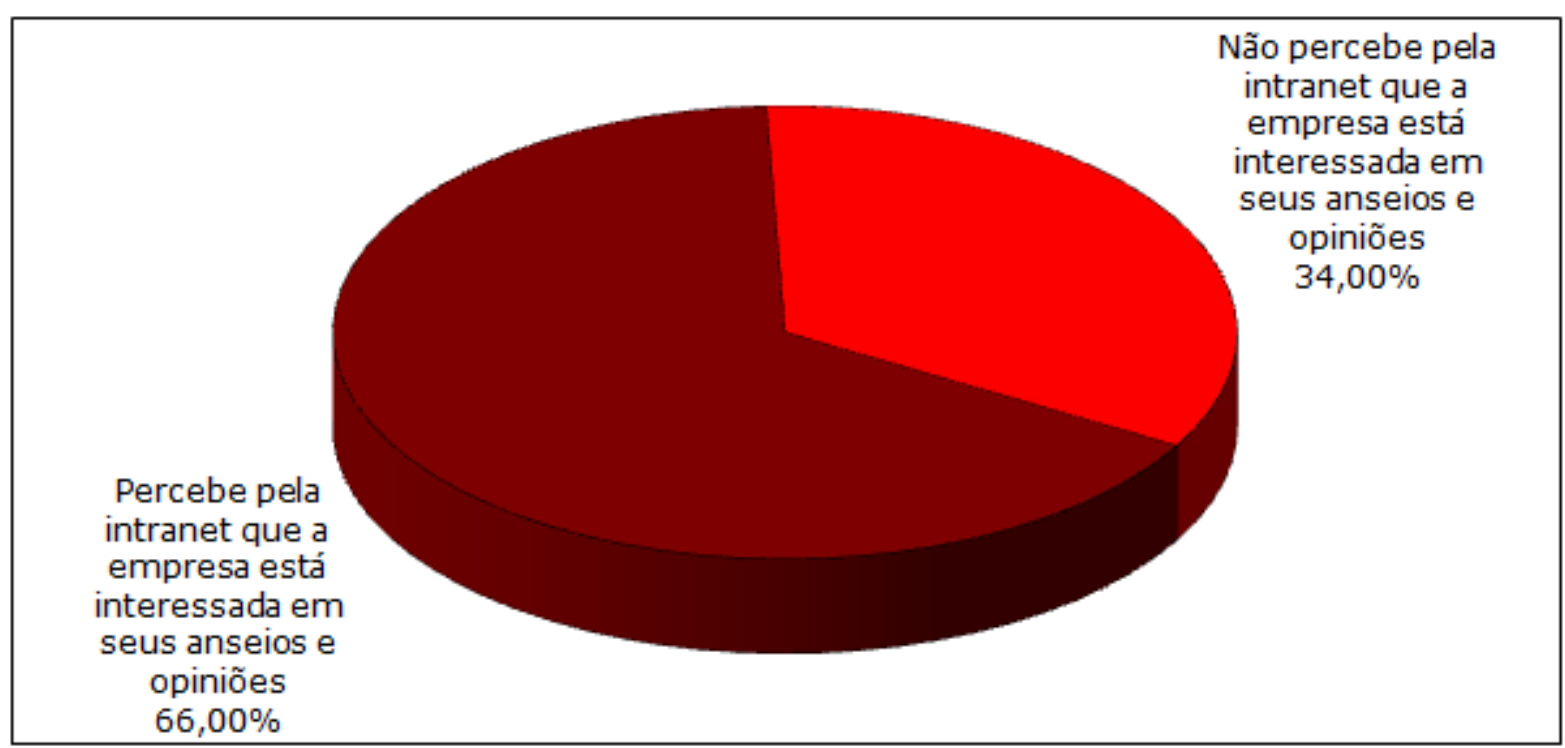

Gráfico 11: Utilizando a intranet você consegue perceber que a organização na qual você trabalha está interessada em seus anseios e opiniões?

Fonte: Dados da pesquisa.

\begin{tabular}{l|c|c|c}
\cline { 2 - 4 } & Freqüência & Percentual & $\begin{array}{c}\text { Percentual } \\
\text { Válido }\end{array}$ \\
\hline $\begin{array}{l}\text { Percebe pela } \\
\text { intranet que a } \\
\text { empresa está } \\
\text { interessada em } \\
\text { seus anseios e } \\
\text { opiniões }\end{array}$ & 33 & $47,14 \%$ & $66,00 \%$ \\
\hline $\begin{array}{l}\text { Não percebe } \\
\text { pela intranet que } \\
\text { a empresa está } \\
\text { interessada em } \\
\text { seus anseios e } \\
\text { opiniões }\end{array}$ & 17 & $24,29 \%$ & $34,00 \%$ \\
\hline $\begin{array}{l}\text { Total } \\
\text { Não } \\
\text { responderam }\end{array}$ & 20 & $28,57 \%$ & $100,00 \%$ \\
\hline Total & 70 & & \\
\hline
\end{tabular}

Tabela 11: Utilizando a intranet você consegue perceber que a organização na qual você trabalha está interessada em seus anseios e opiniões?

Fonte: Dados da pesquisa. 
Por fim, foi questionado se o aluno, como futuro gestor, implementaria a intranet como instrumento de endomarketing nas organizações. Os 5 alunos que responderam, na questão 4, desconhecer o conceito de endomarketing deixaram essa última questão em branco, logo, a amostra, nesse caso, possuía 65 pessoas. Dessas 65 pessoas, 60 responderam que implementariam a intranet como instrumento de endomarketing, totalizando $92,31 \%$, conforme gráfico 12 . Apenas 5 pessoas, ou seja, 7,69\% dos entrevistados afirmaram que não implementariam a intranet como instrumento de endomarketing. O resultado dessa última pergunta demonstra que os formandos em Administração da Universidade de Brasília do $1^{\circ}$ semestre de 2010 estão alinhados às modernas formas de gestão e compreendem que o cliente interno deve ser o primeiro a ser cativado, pois "aos olhos do cliente consumidor, o funcionário é visto como um especialista ou, no mínimo, como alguém que entende do assunto e conhece a 'verdade' sobre a empresa ou produto/serviço e poder ser sincero em suas informações" (CRESCITELLI, 2005, p. 16).

A intranet, enquanto ferramenta de endomarketing, proporciona uma identificação do funcionário com a empresa, uma vez que permite a proximidade com informações pertinentes e necessárias para a execução de suas atividades. Em qualquer empresa, seja pública ou privada, o Gestor deveria sim se preocupar em estruturar mecanismos de endomarketing. (Respondente G)

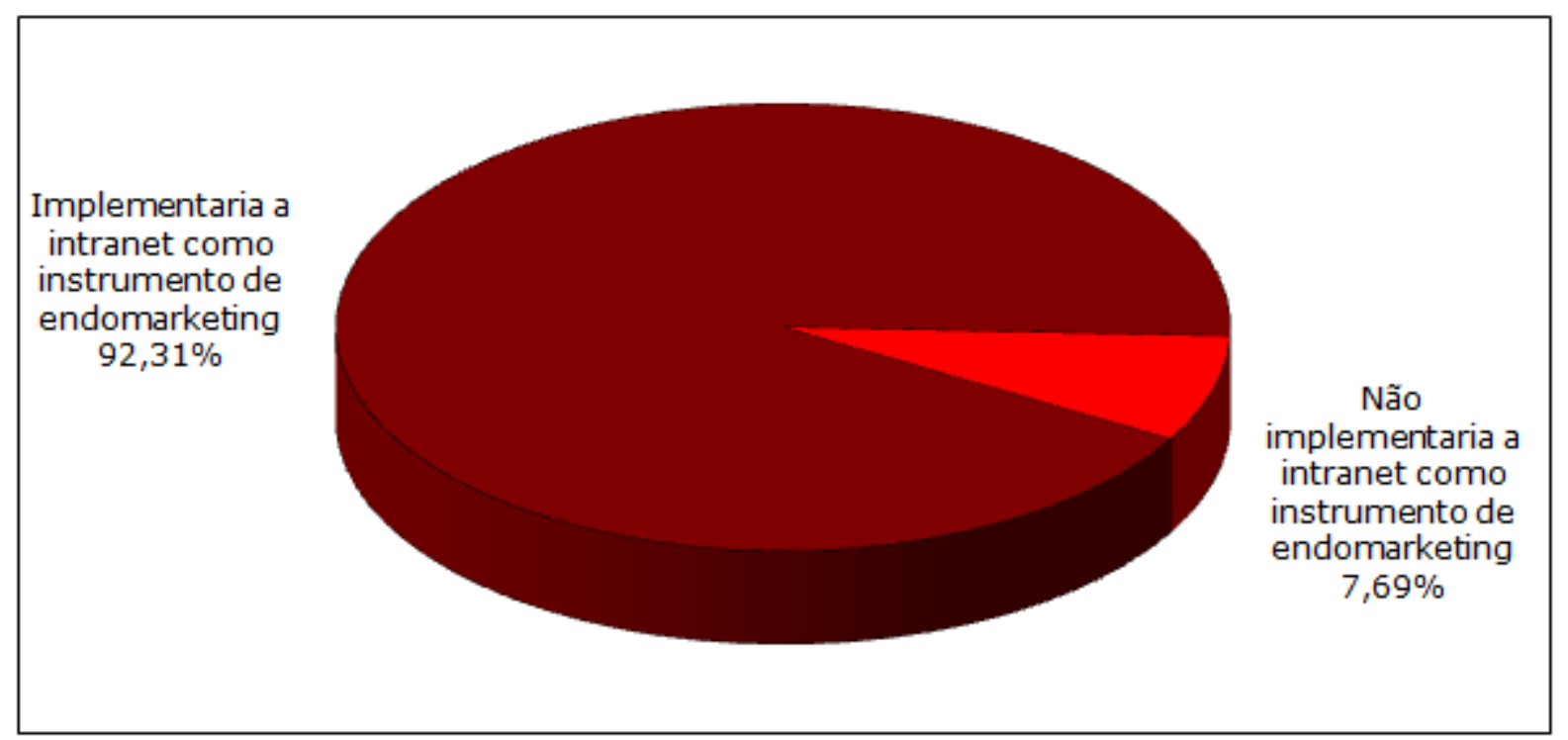

Gráfico 12: Como futuro gestor, você implementaria a intranet como instrumento de endomarketing? Fonte: Dados da pesquisa. 


\begin{tabular}{l|c|c|c}
\cline { 2 - 4 } & Freqüência & Percentual & $\begin{array}{c}\text { Percentual } \\
\text { Válido }\end{array}$ \\
\hline $\begin{array}{l}\text { Implementaria a } \\
\text { intranet como } \\
\text { instrumento de } \\
\text { endomarketing }\end{array}$ & 60 & $85,71 \%$ & $92,31 \%$ \\
\hline $\begin{array}{l}\text { Não } \\
\text { implementaria a } \\
\text { intranet como } \\
\text { instrumento de } \\
\text { endomarketing }\end{array}$ & 5 & $7,14 \%$ & $7,69 \%$ \\
\hline $\begin{array}{l}\text { Total } \\
\text { Não } \\
\text { responderam }\end{array}$ & 65 & $92,86 \%$ & $100,00 \%$ \\
\hline Total & 5 & $7,14 \%$ & \\
\hline
\end{tabular}

Tabela 12: Como futuro gestor, você implementaria a intranet como instrumento de endomarketing? Fonte: Dados da pesquisa 


\section{CONCLUSÕES E RECOMENDAÇÕES}

Este trabalho procurou analisar se a intranet pode ser utilizada como um instrumento eficaz de endomarketing nas empresas. Sabe-se que o endomarketing é uma nova forma de gestão, a qual não está totalmente sedimentada, seja no ambiente organizacional, seja no mundo acadêmico. Contudo, percebe-se que, cada vez mais, o marketing interno está galgando seu espaço na ciência da Administração, visto que, apesar de não ser uma prática unânime, vem sendo, regularmente, utilizada pelas empresas. Dessa maneira, a presente pesquisa procurou demonstrar a importância e os benefícios quando da implementação da gestão de endomarketing.

Para tanto, teve-se a preocupação de trazer a opinião de autores de renome, tanto da literatura nacional, como da literatura internacional. Observou-se, porém, que, por ser um tema relativamente novo, o próprio conceito de endomarketing não se encontra pacificado. Porém, isso não é impedimento para a compreensão do tema haja vista a essência da matéria ser a mesma. Procurou-se, igualmente, expor considerações sobre o que vem sendo apresentado acerca do tema em artigos científicos. Assim, em rápidas palavras, pode-se compreender endomarketing como uma série de ações alinhadas à gestão estratégica da empresa, no intuito de valorizar o funcionário (cliente interno) para que este assimile valores básicos da organização e, assim, conquiste, mais facilmente, o consumidor externo.

O endomarketing pode ser implementado, nas empresas, por meio de diversos instrumentos dentre eles pode-se citar: revistas, jornais internos, datas festivas e comemorativas, cafés da manhã, intranet, etc. A intranet é uma das ferramentas mais modernas no que tange a endomarketing e comunicação interna, motivo pelo qual, foi o objeto de estudo do presente trabalho. Um dos seus principais benefícios é o baixo custo de instalação e manutenção, razão pela qual vem sendo amplamente utilizada. Contudo, a utilização da intranet ainda encontra sérios entraves, dentre os quais, a dificuldade que pessoas leigas encontram quando de seu manuseio.

No intuito de embasar o estudo desta monografia, foi realizada uma pesquisa com os formandos em Administração do $1^{\circ}$ semestre de 2010, da Universidade de 
Brasília, a fim de verificar o nível de conhecimento deles acerca do tema, bem como averiguar se seu ambiente de trabalho enfocava a intranet como instrumento de endomarketing. Além disso, buscou-se compreender como a intranet era utilizada no ambiente organizacional de tais empresas. Assim sendo, foram tecidas diversas perguntas, as quais tinham por suporte embasar a resposta a tais indagações.

No que tange à apuração dos resultados, verificou-se que a ampla maioria dos alunos conhece o conceito de endomarketing. Contudo, percebeu-se que uma quantia considerável de alunos assimilou tal conceito fora da Universidade, visto que nunca tiveram matérias que abordassem o tema.

Com relação à intranet, percebeu-se que a mesma é amplamente utilizada pelas organizações como uma ferramenta que facilita a rotina dos funcionários. É, igualmente, um meio de comunicação eficaz; entretanto, não é capaz de substituir outros meios de comunicação, como o correio eletrônico.

A questão primordial da presente pesquisa estava relacionada ao fato das empresas, por meio da intranet, demonstrarem interesse nos anseios e opiniões de seus funcionários, o que ensejaria a fidelização dos funcionários. A conclusão a que se chegou demonstra que a intranet ainda não é encarada como uma ferramenta consolidada de endomarketing visto que somente $66 \%$ dos alunos entrevistados conseguem perceber que a empresa está, realmente, interessada em seus funcionários. Assim sendo, verifica-se que é necessário que os atuais gestores compreendam a importância e os benefícios de fidelizar o cliente interno.

Contudo, ainda há motivos para se comemorar, haja vista os futuros gestores, leiase os formandos, estarem conectados com as modernas formas de gestão. Corrobora tal afirmativa o fato da ampla maioria ter respondido que implementaria a intranet como ferramenta de endomarketing.

Esse estudo foi muito importante para a aprendizagem pessoal da autora e serviu para demonstrar que temas divergentes podem e devem ser discutidos no mundo acadêmico, pois o debate enriquece o saber.

Conclui-se que esta é uma pesquisa deveras simplista ante a complexidade e modernidade do tema, devendo o mesmo ser aprofundado futuramente. Para estudos posteriores, recomenda-se analisar, não somente a percepção do foco dos funcionários, como também a percepção do foco dos gestores. Assim, os 
questionários deverão ser aplicados com os dirigentes das empresas. Recomendase, ainda, um aumento na produção, tanto nacional, como internacional, de artigos científicos relacionados ao tema. 


\section{REFERÊNCIAS}

ASSOCIAÇÃO BRASILEIRA DE NORMAS TÉCNICAS. NBR 9241-11: requisitos ergonômicos para trabalho de escritórios com computadores - parte 11 orientações sobre usabilidade. Rio de Janeiro: ABNT, agosto de 2002. Disponível em: http://www.inf.ufsc.br/ cybis/pg2003/iso9241-11F2.pdf Acesso em: 13 de junho de 2010.

BARROS, Cristine de. $O$ endomarketing como ferramenta de comunicação interna na agência 3616-1 do Banco do Brasil. Monografia de pós-graduação. UFRGS: Porto Alegre, 2007. Disponível em:

http://www.lume.ufrgs.br/handle/10183/13933?show=full Acesso em: 04 de junho de 2010.

BOHNENBERGER, Maria Cristina; PINHEIRO, Ivan Antônio. Endomarketing - uma ferramenta a ser explorada para obter vantagens competitivas. Disponível em: http://itabi.infonet.com.br/matheusfelizola/artigos_mkt/art_mkt_endomarketing.pdf. Acesso em: 02 de junho de 2010.

BRAMBILLA, Flávio Régio. Abordagem conceitual de marketing interno. REad. Revista Eletrônica de Administração, v.11, oo 1, 2005. Disponível em:

http://read.adm.ufrgs.br/edicoes/pdf/artigo_313.pdf Acesso em: 10 de agosto de 2010.

BRUM, Analisa de Medeiros. Endomarketing: estratégias de comunicação interna para empresas que buscam a qualidade e a competitividade. Porto Alegre: Ortiz, 1998.

CARVALHO, Rodrigo Baroni de. Intranet, portais corporativos e gestão do conhecimento: análise das experiências de organizações brasileiras e portuguesas. Belo Horizonte, 2006.

CERQUEIRA, Wilson. Endomarketing: educação e cultura para a qualidade. Rio de Janeiro: QualityMark, 2002.

CHIAVENATO, Idalberto. Introdução à teoria geral da administração. 6ª ed. rev. atual. Rio de Janeiro: Campus, 2000. 
COBRA, Marcos; BRAGA, Ryon. Marketing educacional: ferramentas de gestão para instituições de ensino. São Paulo: Editora Cobra, 2004.

CONTE, Ezequiel. Intranet na CERTI: um modelo baseado em recursos de enterprise 2.0. UFSC: Florianópolis, 2007. Disponível em:

http://projetos.inf.ufsc.br/arquivos_projetos/projeto_693/Monografia-Ezequiel.pdf Acesso em: 08 de junho de 2010.

CRESCITELLI, Edson. A importância do público interno na comunicação de marketing. FACOM. Revista de Comunicação da FAAP, São Paulo, v. 15, p. 13-19, 2005.

DIAS, Cláudia Augusto. Portal corporativo: conceitos e características. Ci. Inf. [online]. 2001, vol.30, n.1, pp. 50-60. ISSN 0100-1965.

FERRELL, O. C.; HARTLINE, Michael D. Marketing Strategy. 4 edition. Cengage Learning, 2007.

GRESSLER, Lori Alice. Introdução à pesquisa: projetos e relatórios. $2^{\underline{a}}$ ed. ver. atual. São Paulo: Loyola, 2004.

GRÖNROOS, Christian. Marketing: gerenciamento e serviços, a competição por serviços na hora da verdade. Rio de Janeiro: Campus, 1993.

HENRIQUE, Luiz Cláudio Junqueira and BARBOSA, Ricardo Rodrigues. Busca da informação em marketing: a perspectiva da ciência da informação. Rev. adm. empres. [online]. 2009, vol.49, n.2, pp. 221-233. ISSN 0034-7590.

HONORATO, Gilson. Conhecendo o marketing. Barueri: Manuele, 2004.

KEMPENICH, Mario Afonso. Market biruta: como [re]orientar as empresas, os negócios e a si próprio, em termos de rápidas e bruscas mudanças de mercado. $2^{a}$ edição. Salvador: Casa da Qualidade, 1997.

KOTLER, Philip. Administração de Marketing. 10ª edição. São Paulo: Prentice Hall, 2000.

KUNSCH, Margarida Maria Krohling. Planejamento de relações públicas na comunicação integrada. $2^{\underline{a}}$ ed. São Paulo: Summus Editorial, 2002. 
LAUFER, Jaime. A intranet como instrumento de gestão dos sistemas de informações gerenciais. Disponível em:

http://www.abepro.org.br/biblioteca/ENEGEP1998_ART538.pdf Acesso em: 08 de junho de 2010.

LOPES, Claudia. Novas tecnologias: a intranet como fator de mudança para as unidades de informação. Inf. Inf., Londrina, v.6, n.1, jan/jun. 2001.

MARTINS, Leandro. Informática para negócios. São Paulo: Digerati Books, 2007.

MATOS, Gustavo Gomes de. A cultura do diálogo: uma estratégia de comunicação nas empresas. Rio de Janeiro: Elsevier, 2006.

MAXIMIANO, Antônio César Amaru. Introdução à Administração. 5ae ed. rev. e ampl. São Paulo: Atlas, 2000.

MENSHHEIN, Rafael Maurício. Marketing interno. Disponível em:

http://www.portaldomarketing.com.br/Artigos1/Marketing_Interno.htm. Acesso em: 01 de junho de 2010.

MISHRA, Sita. Internal-Marketing: a tool to harness employees' power in service organizations in Índia. International Journal of Business and Management Vol. 5, No.1, January 2010, pp. 185-193.

PEREIRA, Sandra. O poder das redes ou as redes do poder: Análise estratégica numa organização com intranet. Sociologia, maio 2004, no.45, p.99-115. ISSN 08736529.

PIZZINATTO, Andréa Kassouf; PIZZINATTO, Nádia Kassouf; GIULIANI, Antônio Carlos; PIZZINATTO, Nivaldo Kassouf. Marketing interno e cultura organizacional: um estudo de caso em empresa multimarcas. Revista de Administração Mackenzie, América do Norte, 623072008.

RAFIQ, Mohammed; AHMED, Pervaiz K. Advances in the internal marketing concept: definition, synthesis and extension. Journal of Services Marketing, Vol. 14 Iss: 6 , pp.449 - 462 .

Internal marketing: tools and concepts for customer-focused management. Butterworth-Heinemann, 2002. 
Revista Exame - melhores empresas para se trabalhar. Disponível em: http://portalexame.abril.com.br/static/melhoresempresas/\# . Acesso em: 02 de junho de 2010.

RIBEIRO, Walter Eustáquio. Endomarketing em instituições financeiras: um estudo de caso no Banco do Brasil. Monografia de mestrado. Brasília, 1993.

RODRIGUEZ, Martius V.; FERRANTE, Agustín J. Tecnologia de informação e gestão empresarial. Rio de Janeiro: E-papers, 2000.

ROSS, Julio. Redes de computadores. Rio de Janeiro: Antenna Edições Técnicas, 2008.

ROZADOS, Helen Beatriz Frota. A intranet como propulsora da biblioteca acadêmica. Congresso Brasileiro de Biblioteconomia e Documentação, (19.: 2000: Porto Alegre, RS). Anais. Porto Alegre, 2000.

Disponível em:http://www.lume.ufrgs.br/bitstream/handle/10183/10203/000294928.p df?sequence=1 Acesso em: 12 de junho de 2010.

Impactos da intranet em unidades de informação de ensino superior da grande Porto Alegre. Universidade Federal do Rio Grande do Sul. Faculdade de Biblioteconomia e Comunicação. Programa de Pós-Graduação em Comunicação e Informação. Disponível em: http://hdl.handle.net/10183/2906. Acesso em: 08 de junho de 2010.

RUIZ, João Álvaro. Metodologia Científica: guia para eficiência nos estudos. 5a ed. São Paulo: Atlas, 2002.

SAMPAIO e SILVA, Marina Montenegro. Novos olhares sobre endomarketing: o caso da gincana do colégio Anchieta. Disponível em:

http://www.endomarketing.com/diversos/artigo_novosolhares.pdf . Acesso em: 12 de junho de 2010.

SANTOS, Tatiani et al. O desenvolvimento do marketing: uma perspectiva histórica. REGE-USP, São Paulo, v.16, n.1, 2009. Disponível em: http://www.revistasusp.sibi.usp.br/scielo.php?script=sci_arttext\&pid=S1809$22762009000100007 \&$ Ing=pt\&nrm=iso $>$. Acesso em 20 de julho de 2010.

SERRA, Maria José Moreira; VALLE, Clarimar Almeida. A usabilidade da intranet como instrumento de comunicação interna: o caso da Biblioteca Central da Universidade de Brasília. UNB: Brasília, 2006. Disponível em:

http://bdm.bce.unb.br/bitstream/10483/656/1/2006_MariaJoseSilva_ClarimarValle.pdf Acesso em: 12 de junho de 2010. 
SILVA, Severino Francisco da. Marketing de serviço: fundamentos, análises e prática no setor de saúde. Maceió: EDUFAL, 2005.

TACHIZAWA, Takeshy; FERREIRA, Victor Cláudio Paradela; FORTUNA, Antônio Alfredo Mello. Gestão com pessoas: uma abordagem aplicada às estratégias de negócios. 5ª ed. Rio de Janeiro: Editora FGV, 2006.

VASCONCELOS, Anselmo Ferreira. Processo de trocas intra-organizacionais: atualizando o conceito de marketing interno. Caderno de pesquisas em administração, São Paulo, v.11, no 1, janeiro/março de 2004.

VIGNERON, Jacques. Comunicação interna além das mídias. Líbero, Revista Acadêmica de Pós-Graduação da Faculdade de Comunicação Social Casper Líbero. Ano IV, volume 4, no 7-8, 2001

ZANLUCHI, Eliane; DAMACENA, Cláudio; PETROLL, Martin de la Matinière. PROCESSOS COMUNICACIONAIS INTERNOS E SUAS IMPLICAÇÕES NA ORGANIZAÇÃO. Revista de Administração Mackenzie, América do Norte, 72907 2008. 


\section{APÊNDICES}

\section{Apêndice A - Questionário}

\section{Prezado respondente,}

O questionário que você está recebendo tem a finalidade de levantar subsídios para investigar o nível de conhecimento dos formandos em Administração do 1ํ semestre de 2010 da Universidade de Brasília quanto ao tema "Intranet como instrumento de endomarketing". O tempo estimado para resposta é de 05 minutos. Procure ser 0 mais preciso possível em suas respostas. Ao final, não é necessário que você se identifique. Dessa forma, fique à vontade, e responda com a maior sinceridade. Sua ajuda é muito importante para a pesquisa. Obrigada!

\section{Laryssa Maia}

\section{QUESTIONÁRIO}

1. Idade.
a) 21 a 24 anos
b) 25 a 27 anos
c) 28 ou mais

2. Você trabalha?
a) $\quad \operatorname{Sim}$
b) Não

3. Em caso de resposta afirmativa na questão 2, você trabalha:

a) Setor público
b) Setor privado

4. Você sabe o conceito de endomarketing?
a) $\quad \operatorname{Sim}$
b) Não

5. Você teve alguma matéria na universidade que abordou a questão do endomarketing?
a) $\quad \operatorname{Sim}$. 
b) Não

6. Seu ambiente de trabalho possui intranet?

a) $\quad \operatorname{Sim}$

b) Não

7. A intranet facilita seu trabalho?

a) $\quad \operatorname{Sim}$

b) Não

8. A intranet é um meio de comunicação eficaz na empresa onde você trabalha?

a) $\quad \operatorname{Sim}$

b) Não

9. A intranet substitui antigos meios de comunicação na empresa onde você trabalha?

a) $\quad \operatorname{Sim}$

b) Não

10.Utilizando a intranet você consegue obter informações importantes sobre a empresa na qual você trabalha?

a) $\quad \operatorname{Sim}$

b) Não

11.Utilizando a intranet você consegue perceber que a organização na qual trabalha está interessada em você, nos seus anseios e opiniões?

a) $\quad \operatorname{Sim}$

b) Não

12. Como futuro gestor, você implementaria a intranet como instrumento de endomarketing?

a) $\quad \operatorname{Sim}$

b) Não

Você gostaria de deixar algum comentário acerca de endomarketing e/ou intranet? 